\title{
Los derechos individuales del personal laboral de las entidades locales. Especial referencia a las expectativas que abre la «Publificación» de los derechos relacionados con su carrera profesional y su progresión
}

\author{
Josefa Cantero Martínez \\ Profesora Titular de Derecho Administrativo \\ Universidad de Castilla-La Mancha
}

Sumario: I. PLANTEAMIENTO INTRODUCTORIO: EL PROPÓSITO PERSEGUIDO POR EL LEGISLADOR DE EQUIPARAR EL RÉGIMEN DE DERECHOS INDIVIDUALES DE LABORALES Y FUNCIONARIOS. - II. EL PRIMER PASO: APARICIÓN Y RECONOCIMIENTO LEGAL DE UNA RELACIÓN LABORAL DE CARÁCTER ESPECIAL PARA LOS TRABAJADORES DE LA ADMINISTRACIÓN. - III. EL SEGUNDO PASO: EL RECURSO AL NUEVO CONCEPTO DE «EMPLEADO PÚBLICO»COMO TÉCNICA POSIBILITADORA DE LA EQUIPARACIÓN DE AMBOS REGÍMENES. - IV. LA PRETENDIDA UNIFICACIÓN DE DERECHOS EN EL LISTADO DEL ARTÍCULO 14 DEL ESTATUTO BÁSICO DEL EMPLEADO PÚBLICO. ¿ES ELLO REALMENTE POSIBLE? 1. La problemática aplicación de los permisos contemplados en el artículo 48 del Estatuto Básico. El recurso al principio de la norma más favorable y a la «técnica del espigueo». 2. La exclusión del derecho a la inamovilidad como una cuestión más teórica que de efectos prácticos. 3. El reconocimiento del derecho a la promoción interna y a la «progresión en la carrera profesional». Algunas pautas para su desarrollo en la Administración Local. A) La promoción profesional. Especial referencia a la promoción cruzada prevista en la Disposición Transitoria Segunda del Estatuto Básico. B) Algunas consideraciones sobre la posibilidad de introducir un modelo de carrera horizontal también para el personal laboral. Sus premisas. - V. PROBLEMAS PARA QUE LA EQUIPARACIÓN DE AMBOS REGÍMENES JURÍDICOS SEA REAL: UNA CUESTIÓN DE FUENTES.

\section{PLANTEAMIENTO INTRODUCTORIO: EL PROPÓSITO PERSEGUIDO POR EL LEGISLADOR DE EQUIPARAR EL RÉGIMEN DE DERECHOS INDIVIDUALES DE LABORALES Y FUNCIONARIOS}

El régimen de los derechos del personal laboral de la Administración ha sido objeto de un importante grado de «publificación» o «administrativización», toda vez que el Estatuto Básico del Empleado Público (Ley 7/2007, de 12 de abril) ha reconocido a este colectivo, expresamente y por vez primera en nuestro ordenamiento jurídico, los mismos derechos que poseen los funcionarios públicos, a excepción del derecho a la inamovilidad, que sigue siendo exclusivo de éstos. A esta equiparación de derechos se ha llegado inclinando claramente 
la balanza de su regulación hacia el ámbito de lo público, pues hasta la entrada en vigor del Estatuto, los derechos del personal laboral se encontraban regulados en el artículo 4 del Estatuto de los Trabajadores, que contemplaba un listado de derechos básicos que después podía ampliarse y concretarse a través de los correspondientes convenios colectivos y con la libertad que implica en esta materia el principio de autonomía colectiva.

Puede decirse, en consecuencia, que el nuevo régimen no es sino la culminación de un paulatino proceso de acercamiento de los derechos que ya se venía produciendo en la práctica, unas veces por obra de los convenios colectivos y otras por la intervención directa del legislador. Así, los derechos relativos a la protección de derechos fundamentales (la vida, la integridad física o la igualdad) y a la defensa de valores constitucionales (protección de la familia, fundamentalmente) ya habían sido objeto de una regulación conjunta a través de la intervención del legislador durante estos últimos años. En los demás derechos, a excepción de los derechos retributivos y de carrera profesional, tampoco puede decirse que existieran ya dilatadas diferencias. A través de los convenios colectivos se habían ido aproximando los derechos del personal en cada Administración, de tal forma que, con independencia de la naturaleza jurídica de su vínculo, los laborales venían disfrutando ya prácticamente de derechos similares a los de los funcionarios que ostentaban categorías equivalentes o desempeñaban funciones análogas en su Administración.

Pues bien, en las siguientes páginas pretendo analizar cómo se ha producido este fenómeno de equiparación de derechos y si realmente ello es posible, dado el diferente sistema de fuentes al que, en última estancia y a pesar del Estatuto Básico, se someten ambos colectivos, el laboral y el funcionarial. Ello nos sitúa ante un nuevo escenario caracterizado por su gran complejidad, especialmente a la hora de abordar los problemas interpretativos que supone la necesaria armonización e integración de las fuentes del derecho del personal laboral en este ámbito y debido, en buena medida, a la defectuosa técnica jurídica empleada por el legislador básico estatutario para realizar la equiparación, lo que ya está dando lugar a interesantes pronunciamientos jurisprudenciales. Por otra parte, ensayo centrarme fundamentalmente en el ámbito local, por ser éste un ámbito especialmente laboralizado, pues en muchas Administraciones Locales los contratados laborales representan más del $60 \%$ de la plantilla de personal ${ }^{1}$. Asimismo, porque algunas de las propuestas que se efectúan en este trabajo, tales como las que se refieren al desarrollo de un modelo de carrera horizontal para el personal laboral, pueden adquirir una especial significación en este ámbito.

\footnotetext{
1 El personal de la Administración Local (Ayuntamiento, Diputaciones, Cabildos y Consejos Insulares) asciende a 629.505 empleados, lo que representa un 23,8\% del total de empleados públicos. De ellos, 371.331 tienen la condición de personal laboral, sólo 213.985 tienen la condición de funcionario y otros 44.189 la consideración de otro tipo de personal. Es decir, en el ámbito local el personal laboral supera ampliamente al personal funcionarial $(58,98 \%)$ según la información que puede extraerse del Registro Central de Personal. Boletín Estadístico del Personal al Servicio de las Administraciones Públicas, de enero de 2009, págs. 12 y 17, fundamentalmente.
} 


\section{EL PRIMER PASO: APARICIÓN Y RECONOCIMIENTO LEGAL DE UNA RELACIÓN LABORAL DE CARÁCTER ESPECIAL PARA LOS TRABAJADORES DE LA ADMINISTRACIÓN}

La equiparación de los derechos del personal laboral con los del personal funcionarial ha sido, pues, el objetivo perseguido y confesado por el legislador estatutario. Dada la marcada tendencia hacia la unificación de los regímenes jurídicos que se ha producido durante los últimos años en esta materia, se ha entendido que lo más sensato era «recoger y consolidar» en un listado único todos los derechos de aplicación general para todos los empleados públicos ${ }^{2}$. Pero para entender cómo se ha llegado a esta igualación de regímenes jurídicos, no obstante, conviene tener muy presente que la presencia de personal contratado laboral en nuestras Administraciones Públicas no es un fenómeno reciente. Su origen más inmediato hay que encontrarlo en el artículo 7 de la Ley de funcionarios civiles del Estado del año 1964, que contemplaba la posibilidad de que la Administración pudiera hacer uso de esta modalidad contractual sometiéndose por completo al Derecho Laboral. Desde entonces es ya una constante en nuestro ordenamiento jurídico la dualidad de regímenes jurídicos, el funcionarial y el laboral, que conviven en la Administración ocupando en muchas ocasiones puestos de trabajo con funciones similares pero sometidos a regímenes jurídicos completamente diferentes, con las dificultades que ello ocasiona para una adecuada gestión de los recursos humanos y los agravios comparativos que conlleva, especialmente en el tema relativo a sus derechos. Además, ello resulta fundamentalmente llamativo en la Administración Local, por ser ésta un nivel de Administración territorial especialmente laboralizado, al superar incluso este tipo de personal al colectivo funcionarial en muchas de ellas.

La coexistencia de estos dos regímenes jurídicos fue desde muy temprano aceptada por el propio Tribunal Constitucional, principalmente en su Sentencia 57/1982, de 27 de julio, en la que dejó sentado el principio de tratamiento no unitario por diferenciado entre funcionarios y laborales y admitió la plena constitucionalidad de la dualidad de regímenes jurídicos en la Administración ${ }^{3}$.

Durante todos estos años de experiencia, sin embargo, se ha puesto de manifiesto la tensión que en ocasiones se produce entre el Derecho Laboral y el Derecho Administrativo en la regulación de las condiciones de trabajo de los trabajadores de la Administración. Ello se debe a la imposibilidad de que este personal se rija íntegramente por las fuentes del Derecho del Trabajo y así ha

\footnotetext{
2 Utilizo textualmente las palabras empleadas por el Informe de la Comisión de Expertos para el Estudio y Preparación del Estatuto Básico del Empleado Público, dirigido por el profesor Miguel SÁNCHEZ MORÓN y presentado el 25 de abril de 2005 (publicado por el INAP, Madrid, 2005).

3 En el mismo sentido, y entre otras muchas sentencias posteriores, pueden citarse la STC 99/1987, de 11 de junio y la STS de 25 de octubre de 1997.
} 
sido puesto de manifiesto reiteradamente por nuestra jurisprudencia, aunque en ocasiones no existiera apoyo legal para ello. Al mismo tiempo, en los últimos años se ha ido produciendo en paralelo una clara propensión hacia la laboralización de la función pública española. Además de la incorporación de contratados laborales a la Administración y de los procesos de privatización de importantes sectores de su actividad que han llevado a la doctrina a hablar de una «huida del Derecho Administrativo», esta tendencia se ha manifestado de forma muy significativa en la introducción en el ámbito funcionarial de instituciones que tradicionalmente han sido propias y exclusivas del Derecho del Trabajo, tales como por ejemplo la huelga, la negociación colectiva, los planes de empleo, etc. Todo ello ha contribuido a difuminar progresivamente las férreas fronteras que en otro tiempo existieron entre el Derecho Laboral y del Derecho funcionarial.

La contratación de personal laboral se produjo inicialmente de forma completamente discrecional, toda vez que el artículo 7 de la Ley de 1964, tal como acabamos de apuntar, únicamente preveía para su contratación la previa autorización reglamentaria. La ausencia de todo tipo de controles administrativos y la aplicación íntegra del Estatuto de los Trabajadores (tal como todavía sigue hoy recogiendo el art. 107.2 del Real Decreto Legislativo 781/1986), y en concreto de la sanción que prevé su artículo 15 para la contratación temporal irregular, acabaron en no pocas ocasiones convirtiendo esta modalidad de acceso a la Administración en una puerta falsa que ha permitido, no sólo la entrada, sino también la permanencia en la Administración, de personas que no habían acreditado suficientemente su mérito y capacidad, dando así amparo a todo tipo de comportamientos clientelares y nepóticos. Para evitar este tipo de situaciones, el propio legislador tuvo que reaccionar exigiendo el cumplimiento escrupuloso de los mismos principios y estableciendo idénticos procesos para la selección de todo su personal, ya fuera funcionario o laboral. Buena muestra de ello es el art. 103 de la Ley 7/1985 de bases de régimen local.

Es decir, desde las propias normas administrativas se empezaron a establecer las principales notas que ahora han permitido al legislador estatutario básico del año 2007 la configuración de una relación laboral de carácter especial para los trabajadores de la Administración. En otras ocasiones, sin embargo, esta atracción del régimen laboral hacia el Derecho público ha sido obra de la labor interpretativa de nuestros jueces y tribunales, sin el apoyo expreso de ninguna norma legal, por no decir en clara contradicción con lo previsto en el artículo 7 de la Ley de funcionarios de 1964 que, como antes hemos señalado, contemplaba para estos trabajadores una aplicación integra del ordenamiento laboral, sin excepción.

Efectivamente, nuestra jurisprudencia ha puesto de manifiesto que resulta completamente imposible una total aplicación de las normas privadas en el ámbito del empleo público, lo que se ve especialmente reflejado en todo el régimen de acceso y carrera del personal laboral. La naturaleza pública de la Administra- 
ción y su servicio a los intereses generales han impedido asimilar la figura de la Administración a la de cualquier empresario privado. Los principios constitucionales de igualdad, mérito, capacidad y publicidad han justificado una modulación - a veces inaplicación - de diversos preceptos del Estatuto de los Trabajadores. En concreto, estas especialidades han impedido, por ejemplo, que en el supuesto de contratación temporal irregular el trabajador pudiera convertirse en personal fijo de plantilla, tal como sancionaba inicialmente el artículo 15 del Estatuto de los Trabajadores ${ }^{4}$, o que en aquellos supuestos en que el despido fuera declarado nulo o improcedente pudiera producirse la reincorporación del trabajador a la Administración y la adquisición de la condición de fijo de plantilla, tal como disponía el Estatuto de los Trabajadores, o que se establecieran también peculiaridades en los supuestos en que la Administración ejercitara su ius variandi y atribuyera al trabajador funciones de categoría superior.

Estas especialidades, sin embargo, planteaban importantes problemas de legitimación. Todas ellas estaban siendo introducidas por obra de la jurisprudencia y, hasta el momento, sin ningún apoyo legislativo 5 . A mi juicio, ello podía provocar un serio problema de compatibilidad con el principio de legalidad, que en este caso y tal como disponía el artículo 7 de la Ley de Funcionarios de

\footnotetext{
4 Aunque la postura del Tribunal Supremo en materia de irregularidades cometidas por las Administraciones Públicas en materia de contratación laboral no ha respondido nunca a criterios uniformes, en los últimos años ha consolidado el criterio de que «la contratación laboral en la Administración Pública al margen de un sistema adecuado de ponderación de mérito y capacidad impide equiparar a los demandantes a trabajadores fijos de plantilla, condición ligada a la contratación por el procedimiento reglamentario, sin perjuicio de su consideración, en su caso, como trabajadores vinculados por un contrato de trabajo por tiempo indefinido» (entre otras muchas, véanse la STS de 20 de enero de 1998 y la STS de 27 de mayo de 2002). Para profundizar sobre esta problemática cuestión nos remitimos, entre otros muchos autores, a GODINO REYES, Martín, «La problemática de la contratación laboral en la Administración Local», Revista Española del Derecho del Trabajo, n. ${ }^{\circ}$ 81, 1997; PRADOS DE REYES, Francisco, «Las peculiaridades de la relación de trabajo en el empleo público (I)», Actualidad Laboral, n. ${ }^{\circ}$ 16, 1990; MARTínEZ ABASCAL, Vicente Antonio, La laboralización de la Función Pública, 1996; FOLGUERA CRESPO, José, «Contratación temporal de las Administraciones Públicas. Diversidad de criterios jurisdiccionales», Actualidad Laboral, n. 18, 1992; GARCÍA LÓPEZ, Rafael, «La contratación laboral temporal en las Administraciones Públicas», Revista Española del Derecho del Trabajo, n. ${ }^{\circ}$ 44, 1990; LANDA ZAPIRAin, Juan Pablo, Collado LuIs, Santiago, SANTIAGo REDONDO, Koldo Mikel, TENES ITURRI, Raúl, La contratación laboral temporal en las Administraciones Públicas, Civitas, 1993; NiCOLÁs BERNARD, José Alberto, «La contratación temporal irregular en la Administración Pública: evolución jurisprudencial», Aranzadi Social, n. ${ }^{\circ}$ 5, 2000, págs. 427-454; CASTILlo BLANCO, Federico, «Las problemáticas fronteras entre el Derecho Laboral y el Derecho Administrativo: a propósito de los contratos temporales en el sector público», Revista Española de Derecho Administrativo, n. ${ }^{\circ}$ 86, 1995; CANTERo MARTíneZ, Josefa, «Ámbito de aplicación y clases de personal al servicio de las Administraciones Públicas», Comentarios al Estatuto Básico del Empleado Público, obra colectiva dirigida por Luis Ortega Álvarez, publicada por la Ley (el Consultor) en el año 2007, etc.

5 Téngase en cuenta, no obstante, que algunas de estas modificaciones han requerido ya la intervención del legislador. Así, puede traerse a colación la nueva Disposición Adicional Decimoquinta introducida en el Estatuto de los Trabajadores por la Ley 43/2006, de 29 de diciembre, sobre la aplicación de los límites al encadenamiento de contratos en las Administraciones Públicas. A tenor de dicho precepto, la sanción de indefinición de los contratos prevista en el párrafo quinto del artículo 15 del Estatuto de los Trabajadores «surtirá efectos en el ámbito de las Administraciones públicas y sus organismos autónomos, sin perjuicio de la aplicación de los principios constitucionales de igualdad, mérito y capacidad en el acceso al empleo público, por lo que no será obstáculo para la obligación de proceder a la cobertura de los puestos de trabajo de que se trate a través de los procedimientos ordinarios, de acuerdo con lo establecido en la normativa aplicable».
} 
1964, exigía que la Administración se sometiera íntegramente al Derecho Laboral cuando actuara como empresario y celebrara un contrato de trabajo. Por otro lado, y lo que podía resultar todavía más comprometido, estas especialidades estaban motivando la aparición de una relación de trabajo especial parestatutaria para el personal laboral de la Administración ${ }^{6}$, un nuevo régimen jurídico mixto para sus trabajadores, a caballo entre la normas administrativas y las normas laborales, que no tenía ninguna expresa previsión normativa y que se caracterizaba por el sometimiento del trabajador de la Administración al Derecho Laboral y, en buena parte, también al Derecho Público.

En otras ocasiones, estos mismos principios y estas especialidades de la Administración se habían traducido en una atracción de la normativa laboral hacia el ámbito de lo público y en una regulación unitaria, y en ocasiones paralela, de ambas modalidades de personal. Esto es lo que había ocurrido, por ejemplo, en materia de acceso a la Administración; ámbito en el que el legislador se vio ya obligado a introducir exactamente los mismos procedimientos para la selección del personal, con total independencia de la naturaleza de su vínculo con la Administración. Lo mismo había ocurrido en materia de incompatibilidades, aunque esta vez fue el principio de eficacia e imparcialidad de la actuación administrativa lo que había justificado la introducción del mismo régimen jurídico para todo el personal de la Administración ${ }^{7}$.

Otras veces ha sido la propia naturaleza de los fondos con los que se gestiona el empleo público y la función de dirección de la actividad económica del Estado (art. 149.1.13 de la Constitución) lo que ha motivado la inaplicación del Derecho Laboral en este ámbito. Al provenir el dinero de los presupuestos públicos y al tener atribuidas las Cortes Generales la potestad soberana para aprobar las distintas partidas presupuestarias, ha sido necesario fijar unos topes máximos salariales también para la negociación colectiva, así como el establecimiento de un procedimiento de naturaleza pública plagado de controles y autorizaciones gubernativas que son absolutamente desconocidos en el ámbito de las relaciones laborales.

En definitiva, pues, la experiencia nos ha mostrado que ni siquiera para el personal laboral es constitucionalmente posible una aplicación íntegra del Derecho del Trabajo en la Administración. Necesariamente tienen que existir determinadas especialidades que justifican perfectamente la inserción de normas de Derecho Público en este ámbito. Ello ha sido razón de suficiente peso para que en estos años el legislador haya considerado oportuno regular de forma paralela y en un mismo texto legal importantes aspectos de su régimen jurídico.

\footnotetext{
6 Para un tratamiento más detallado y profundo de todos los problemas jurídicos que ha planteado esta cuestión me remito a CANTERO MARTINEZ, Josefa, El empleo público: entre estatuto funcionarial y contrato laboral, Marcial Pons, Madrid, 2001, págs. 456 y ss.

7 Ley 53/1984, de 26 de diciembre, de Incompatibilidades del Personal al Servicio de las Administraciones Públicas.
} 
En otras ocasiones, y en lo no expresamente previsto por el legislador, ha sido la negociación colectiva la que se ha encargado de aproximar el régimen jurídico del personal laboral al funcionarial, hasta hacer desaparecer casi por completo los privilegios que han caracterizado tradicionalmente al funcionario. Es lo que ha ocurrido con el régimen de los derechos individuales del personal laboral, con la única excepción del derecho a la inamovilidad, que sigue siendo exclusivo del personal funcionarial.

A mi juicio, ésta es una de las principales aportaciones del nuevo Estatuto Básico del Empleado Público: dar cobertura legal a esta relación laboral de carácter especial que se había venido paulatinamente forjando durante todos estos años. El Estatuto se erige como principal fuente del derecho para el personal laboral. Sólo en lo no dispuesto en el Estatuto básico, que regula las especialidades del empleo público en la Administración y configura lo que podría denominarse una «relación laboral especial», habrá de aplicarse la legislación laboral común y su propio sistema de fuentes. En este sentido, el artículo 7 del Estatuto Básico se muestra contundente al disponer que «el personal laboral al servicio de las Administraciones Públicas se rige, además de por la legislación laboral y por las demás normas convencionalmente aplicables, por los preceptos de este Estatuto que así lo dispongan».

Esta contundencia, sin embargo, no significa que no se puedan plantear problemas interpretativos a la hora de aplicar el régimen de derechos al personal laboral de la Administración. Esta situación resulta especialmente confusa en el ámbito de las Entidades Locales pues en esta materia, desafortunadamente y al igual que ocurre con otras instituciones contempladas en el Estatuto, además de las fuentes laborales nos encontramos con una duplicidad de fuentes jurídicas administrativas: el bloque de legislación básica funcionarial contemplado de forma dispersa en varias normas estatales y la legislación básica en materia de régimen local. Ello hace que nos encontremos con algunos preceptos del marco de regulación previsto en el régimen local que, a pesar de no haber sido expresamente derogados por el Estatuto Básico del Empleado Público, resultan a día de hoy inaplicables o, al menos, deben ser objeto de interpretación y modulación para adaptarlos a la nueva filosofía unificadora que inspira el nuevo Estatuto. Buena muestra de ello encontramos en algunos de los escasos preceptos de la normativa local que se refieren al régimen de su personal laboral. Así ocurre, a nuestro juicio, con el segundo párrafo del art. 177 del Real Decreto Legislativo 781/1986, de 18 de abril, por el que se aprueba el Texto Refundido de las disposiciones legales vigentes en materia de régimen local, a cuyo tenor, y cito textualmente, «la contratación laboral puede ser por tiempo indefinido, de duración determinada, a tiempo parcial, y demás modalidades previstas en la legislación laboral. El régimen de tales relaciones será, en su integridad, el establecido en las normas de Derecho Laboral».

En buena técnica jurídica, este precepto habría de entenderse, cuando menos, implícitamente derogado por el nuevo régimen establecido en el Estatuto Básico, lo que introduce para los gestores del personal local un importante gra- 
do de complejidad jurídica e incertidumbre en esta materia. Es lo que ocurre, por ejemplo, con la remisión íntegra al Derecho Laboral que prevé este precepto o con la referencia a las dos posibles modalidades contractuales, por tiempo indefinido o de duración determinada ${ }^{8}$. Como acabamos de señalar, esta remisión íntegra no es posible en nuestro ordenamiento jurídico. Por el contrario, ha sido necesario reconocer que la aplicación del Derecho Laboral en el ámbito de la Administración está sometida a tantas y tan substanciales modulaciones que ha sido necesario crear una relación laboral de carácter especial para contemplarlas y para crear un marco de mayor seguridad jurídica. Significa ello que prioritariamente el régimen de este personal hay que buscarlo ahora en el Estatuto Básico y, sólo en lo no previsto en éste, en las propias fuentes del Derecho del Trabajo, esto es, en el Estatuto de los Trabajadores y en los correspondientes convenios colectivos que resulten aplicables, según se desprende de la interpretación más lógica y racional que puede hacerse del régimen de prelación de fuentes dispuesto en el art. 7 del Estatuto Básico.

A los problemas interpretativos que puede suponer la coexistencia de diferentes fuentes jurídicas habría que añadir los defectos de técnica jurídica del legislador que se observan en el Estatuto por el continuo juego de remisiones entre preceptos. Ello no hace sino ahondar todavía más en la complejidad jurídica que ya plantea esta materia, tal como puede apreciarse, por ejemplo, a la hora de determinar la aplicabilidad al personal laboral del listado de permisos contemplados en el artículo 48 del Estatuto Básico para los funcionarios y a tenor de lo dispuesto en su artículo 51. De ello nos ocuparemos, no obstante, más adelante.

\section{EL SEGUNDO PASO: EL RECURSO AL NUEVO CONCEPTO DE «EMPLEADO PÚBLICO» COMO TÉCNICA POSIBILITADORA DE LA EQUIPARACIÓN DE AMBOS REGÍMENES}

La constatación de la realidad que acabamos de describir en el epígrafe anterior no sería suficiente para explicar la decisión del legislador estatutario de avanzar hacia el establecimiento de una categoría única de empleados públicos. Ello sólo resulta entendible si se tienen en cuenta los trascendentales cambios que, al mismo tiempo y de forma paralela, se estaban produciendo en el régimen funcionarial y que habían ocasionado una profunda desvirtuación de los postulados teóricos de la relación estatutaria.

\footnotetext{
8 Lo mismo puede decirse de la remisión que realiza la normativa local a las posibles modalidades de contratación laboral, pues las nuevas modalidades de contratación ya no responden exactamente a las dos únicas categorías que se menciona el precepto citado ni tienen en mismo significado jurídico. Ahora la contratación laboral puede ser temporal, fija o indefinida y esta última categoría ha sido construida por el legislador a raíz de la jurisprudencia y con unos matices que poco o nada tienen que ver con los que poseía esta figura laboral en los años ochenta.
} 
El reconocimiento a los funcionarios del derecho fundamental de sindicación desde el propio Texto Constitucional, y de los derechos de huelga y de negociación colectiva en los textos legales, suponía un auténtico revés para la concepción clásica estatutaria y las bases ideológicas, que no sólo la habían sustentado, sino que habían permitido además justificar el sometimiento de los funcionarios a un régimen jurídico particular completamente distinto del aplicable en el ámbito privado.

Por otra parte, tampoco tiene hoy en día mucho sentido seguir manteniendo las condiciones de rigidez que han caracterizado clásicamente al funcionario público en materia de inamovilidad en el puesto, sistema retributivo y asignación de tareas bajo el pretexto de garantizar su imparcialidad. La objetividad e imparcialidad debe avalar el ejercicio de las funciones de todo el personal de la Administración porque ello es una exigencia constitucional del servicio objetivo a los intereses generales que proclama el artículo 103.1 de la Constitución y que ahora recoge como novedad para todos los empleados el artículo 52 del Estatuto. Las técnicas para lograr este objetivo no necesariamente se tienen que plasmar en el reconocimiento de un estatus excesivamente particular y privilegiado para una sola de estas categorías de personal. La imparcialidad, entendida como falta de prejuicio a la hora de realizar la actividad administrativa, puede quedar garantizada a través de otras técnicas esenciales, fundamentalmente con el establecimiento de un riguroso sistema de incompatibilidades y con la previsión de determinadas causas de abstención y recusación, cuya concurrencia hace presumir que la actuación del empleado no es imparcial. Y estas técnicas se aplican por igual a los funcionarios y a los contratados de la Administración.

Ante esta situación, no es de extrañar que algunos autores hubieran puesto de manifiesto la necesidad de superar una tajante distinción entre el régimen laboral y el funcionarial y de avanzar hacia el establecimiento de una regulación que, en la medida de lo posible y de lo constitucionalmente permitido, fuera homogénea para ambas modalidades de personal ${ }^{9}$. Por todo lo dicho, no tendría demasiado sentido que este estatuto al que hace referencia el artículo 103.3 de la Constitución fuera completamente diferente del aplicable al resto de los trabajadores de la Administración. Y esta es la idea básica que trasluce el nuevo Estatuto Básico del empleado público, que viene a configurarse como la norma básica que contempla únicamente aquellas especialidades que vengan exigidas por la propia naturaleza pública de la Administración y por la vigencia de determinados principios constitucionales que, directa o indirectamente, hacen referencia al empleo en la Administración. Me estoy refiriendo a los principios de igualdad, mérito, capacidad, publicidad, jerarquía, eficacia y objetividad, toda vez que ellos sí que justifican la aplicación a los funcionarios públicos de un régimen que se aparte del aplicable al resto de los trabajadores.

9 Me remito a mi trabajo sobre El empleo público: entre estatuto funcionarial y contrato laboral, Marcial Pons, 2001, así como a la bibliografía allí citada. 
De otra parte, y dada la atracción que hacia al ámbito de lo público se está produciendo de las normas laborales que se aplican a los trabajadores de la Administración, se ha considerado conveniente que el Estatuto recogiera también su específico régimen jurídico que, como hemos señalado antes, no puede ser totalmente el Derecho Laboral. Pues bien, visto que el régimen funcionarial tiende a laboralizarse y comprobado que el régimen laboral aplicable a la Administración propende a administrativizarse, parecía lógica la confluencia de estos dos procesos en un estatuto único, que es lo que ha venido a hacer el nuevo Estatuto Básico. El Estatuto viene a configurar una nueva relación laboral de carácter especial que contempla aquellas especificidades que ha ido poniendo de manifiesto la jurisprudencia para los trabajadores de la Administración. Ello permite unificar los principios rectores y requisitos para la adquisición de la condición de empleado público; el establecimiento de un contenido unitario en cuanto a los derechos y deberes de los empleados públicos; la aplicación de un mismo código de conducta para todos ellos; el reconocimiento de la posibilidad de conformar órganos de negociación conjunta para los funcionarios y los laborales o la unificación en materia de régimen disciplinario, etc.

Ante este panorama, no tendría sentido, pues, seguir distinguiendo entre funcionarios y laborales para referirse al personal de la Administración y al vínculo que los une con ésta como si de dos realidades completamente diferentes se tratara. Lo razonable, por el contrario, es seguir avanzando en esa tendencia hacia la regulación conjunta de las condiciones de trabajo y, en consecuencia, hacia el establecimiento de una única categoría general de empleados públicos para que, a partir de la misma, puedan después individualizarse aquellos aspectos del régimen jurídico de cada una de estas modalidades de personal, en atención fundamentalmente al distinto encuadre constitucional que posee cada una de ellas: el artículo 103.3 para los funcionarios públicos y el artículo 35.2 para los trabajadores de la Administración, ambos sometidos a reserva de ley y a la competencia exclusiva del Estado (art. 149.1.18 y 149.1.7), aunque con distinto alcance.

Y esta es la idea básica que ha trascendido al nuevo Estatuto Básico, que en vez de utilizar la técnica de extender al personal laboral importantes aspectos del régimen jurídico funcionarial, tal como hasta ahora venía realizando el legislador, ha decidido cimentar un nuevo concepto, el de empleado público, para referirse de forma global a todos aquellos empleados que desempeñan funciones retribuidas en las Administraciones Públicas al servicio de los intereses generales (art. 8 del Estatuto).

El concepto de empleado público abarca, pues, las dos modalidades de personal que pueden prestar sus servicios en una Administración: los funcionarios y los laborales. Esta concepción amplia del empleado público no es en sí mismo ninguna novedad porque importantes aspectos del régimen jurídico funcionarial ya venían aplicándose por igual a todos los empleados con independencia de la naturaleza de su vínculo con la Administración, tal como ocurría, por 
ejemplo, con el acceso a la Administración, con los topes presupuestarios en la negociación colectiva o con el sistema de incompatibilidades. La principal novedad, en este sentido, vendría dada por la nueva terminología utilizada y por la filosofía inspiradora del Estatuto de avanzar en este proceso de confluencia de regímenes mediante la reducción de las diferencias existentes entre ambas modalidades de personal.

Esta solución parece la más razonable. Su adecuada puesta en funcionamiento exige establecer una regulación conjunta para ambos tipos de personal, en todo aquello que sea necesario por derivarse así de los principios constitucionales o de la propia naturaleza pública del empleador. Se trata, pues, de recopilar todas aquellas prescripciones que deben distinguir y singularizar a los empleados que prestan sus servicios en la Administración frente a quienes lo hacen en el sector privado. Y esto precisamente es lo que ha venido a hacer el Estatuto Básico en materia de derechos del personal laboral. A partir de estas reglas comunes, cada clase de empleado público estará sometido después a su propio régimen jurídico y a sus propias fuentes.

\section{LA PRETENDIDA UNIFICACIÓN DE DERECHOS EN EL LISTADO DEL ARTÍCULO 14 DEL ESTATUTO BÁSICO DEL EMPLEADO PÚBLICO. ¿ES ELLO REALMENTE POSIBLE?}

Al personal laboral de la Administración Local le resulta aplicable todo el elenco de derechos de naturaleza individual contenido en el artículo 14 del Estatuto Básico, excepto el de la inamovilidad, que sigue siendo exclusivo de los funcionarios públicos. Ello supone una importantísima novedad, en la medida en que unifica por vez primera en nuestro ordenamiento jurídico los derechos del personal laboral con los del personal funcionarial, al menos en su enunciación formal, pues otra cosa será el contenido que se le acabe dando finalmente a los mismos. Resulta destacable, asimismo, la publificación o administrativización de que ha sido objeto esta materia, toda vez que esta igualación de derechos se ha producido inclinando claramente la balanza hacia el lado de lo público, esto es, reconociendo a los laborales de la Administración los mismos derechos que poseen los funcionarios, lo cual abre interesantes expectativas para este colectivo, tal como, a mi juicio, puede suponer el reconocimiento del derecho a la carrera profesional. Y esto es así porque el legislador, con buen criterio, ha partido de la idea esencial de que no tiene sentido que posean derechos disímiles colectivos que en muchas ocasiones realizan idénticas labores dentro del organigrama administrativo.

La amplitud del listado de derechos individuales de los laborales de la Administración contrasta notablemente con la parquedad de derechos de naturaleza laboral establecida en el párrafo segundo del artículo 4 del Estatuto de los 
Trabajadores. Así, según lo dispuesto en el art. 14 del Estatuto Básico, todos los empleados públicos - se incluye, por tanto, al personal laboral - , tienen los siguientes derechos de carácter individual en correspondencia con la naturaleza jurídica de su relación de servicio:

a. A la inamovilidad en la condición de funcionario de carrera.

b. Al desempeño efectivo de las funciones o tareas propias de su condición profesional y de acuerdo con la progresión alcanzada en su carrera profesional.

c. A la progresión en la carrera profesional y promoción interna según principios constitucionales de igualdad, mérito y capacidad mediante la implantación de sistemas objetivos y transparentes de evaluación.

d. A percibir las retribuciones y las indemnizaciones por razón del servicio.

e. A participar en la consecución de los objetivos atribuidos a la unidad donde preste sus servicios y a ser informado por sus superiores de las tareas a desarrollar.

f. A la defensa jurídica y protección de la Administración Pública en los procedimientos que se sigan ante cualquier orden jurisdiccional como consecuencia del ejercicio legítimo de sus funciones o cargos públicos.

g. A la formación continua y a la actualización permanente de sus conocimientos y capacidades profesionales, preferentemente en horario laboral.

h. Al respeto de su intimidad, orientación sexual, propia imagen y dignidad en el trabajo, especialmente frente al acoso sexual y por razón de sexo, moral y laboral.

i. A la no discriminación por razón de nacimiento, origen racial o étnico, género, sexo u orientación sexual, religión o convicciones, opinión, discapacidad, edad o cualquier otra condición o circunstancia personal o social.

j. A la adopción de medidas que favorezcan la conciliación de la vida personal, familiar y laboral.

k. A la libertad de expresión dentro de los límites del ordenamiento jurídico.

1. A recibir protección eficaz en materia de seguridad y salud en el trabajo.

m. A las vacaciones, descansos, permisos y licencias.

n. A la jubilación según los términos y condiciones establecidas en las normas aplicables.

o. A las prestaciones de la Seguridad Social correspondientes al régimen que les sea de aplicación.

p. A la libre asociación profesional.

q. A los demás derechos reconocidos por el ordenamiento jurídico. 
El listado recoge todos los derechos homónimos contemplados en la normativa laboral, aunque en algunos de ellos introduce ciertos matices de interés, como ocurre con la mención que realiza el apartado h) del art. 14 al referirse al «acoso laboral» como figura diferenciada de otras formas de acoso hasta ahora recogidas en el Estatuto de los Trabajadores ${ }^{10}$, con el derecho al desempeño efectivo de las funciones de acuerdo con la progresión alcanzada en su carrera profesional, que aporta un contenido bastante más enriquecedor que el mero derecho a la ocupación efectiva que menciona la letra a) del artículo 4.2 del Estatuto de los Trabajadores, o con los derechos a participar en la consecución de los objetivos y a ser informado por sus superiores de las tareas a desarrollar, por citar tan sólo algunos de ellos. Otros son nuevos o no encuentran exactamente su equivalente en este ámbito. Así sucede, por ejemplo, con el derecho a «la defensa jurídica y protección de la Administración Pública en los procedimientos que se sigan ante cualquier orden jurisdiccional como consecuencia del ejercicio legítimo de sus funciones o cargos públicos».

Algunos de estos derechos tienen como claro propósito la protección de derechos fundamentales y de valores constitucionales, lo que explica que en esta materia ya se hubiera atisbado una clara tendencia hacia la equiparación de regímenes por obra de la propia regulación sectorial. Es lo que ha ocurrido con la protección del derecho a la vida e integridad física frente a los riesgos relacionados con el trabajo que persigue el derecho enumerado en la legra 1) del precepto. Una de las novedades introducidas por la Ley 31/1995, de 8 de noviembre, de prevención de riesgos laborales, fue efectivamente su extensión al ámbito de las Administraciones Públicas, razón por la cual se le reconoció no sólo el carácter de legislación laboral sino también de norma básica del régimen estatutario de los funcionarios públicos. A partir del reconocimiento del derecho de los trabajadores en el ámbito laboral a la protección de su salud e integridad se produjo la unificación de regímenes jurídicos. Si lo que se pretendía era realizar un tratamiento global e integral de los riesgos relacionados con el trabajo, la protección habría de ser la misma cualquiera que fuera el ámbito en el que éste se prestara y con total independencia de la naturaleza laboral o funcionarial del vínculo que les uniera con su empleador.

En otros casos, la regulación establecida en el Estatuto resulta mucho más beneficiosa que la recogida en el artículo 4 del Estatuto de los Trabajadores, a

\footnotetext{
10 Seguimos en este punto a DEL REY GUANTER, Salvador, «Empleo público y empleo privado: reflexiones a la luz del Estatuto Básico», en la obra colectiva titulada Comentarios al Estatuto Básico del Empleado Público, dirigida por Salvador DEL REY GuANTER, Manuel FÉREZ FERnÁNDEZ y Esther SÁNCHEZ TORRES, La Ley, 2008, págs. 112 y ss. Resalta el autor que el concepto de acoso laboral es diferente de los conceptos que utiliza el Estatuto de los Trabajadores, pues hasta ahora sólo se ha contemplado el acoso sexual, el acoso por razón de sexo y el acoso por orientación sexual, a lo que se ha unido el acoso por razón de origen racial o étnico, religión o convicción, discapacidad o edad, pero no ha existido una conceptuación jurídica positiva diferenciada de un acoso laboral. El denominado mobbing o acoso moral se refería a una conducta de acoso que podría englobar las causas menos tratadas legalmente que las de acoso sexual o por razón de sexo, ahora específicamente recogidas en el art. 7 de la Ley 3/2007, de 22 de marzo, para la igualdad efectiva de mujeres y hombres.
} 
pesar del tratamiento también común de que había sido objeto esta materia, en este caso, a través de la Ley Orgánica 1/2004, de 28 de diciembre, de medidas de protección integral contra la violencia de género. Esto es lo que sucede, por ejemplo, con el régimen previsto para la movilidad por violencia de género, toda vez que el artículo 82 del Estatuto Básico, al desarrollar los derechos relacionados con la protección de la vida e integridad física de la mujer que es víctima de violencia de género, les reconoce el derecho al traslado a otra localidad distinta, sin necesidad de que exista una vacante de necesaria cobertura ${ }^{11}$. Habrá que ver, no obstante, cómo se puede articular el cumplimiento de esta obligación de traslado en las Entidades Locales, especialmente en las más pequeñas, pues su efectividad difícilmente podrá ser real si no es con el auxilio de la Diputación y con el acuerdo entre las distintas Entidades.

Lo mismo ha sucedido en materia de conciliación de la vida laboral y familiar. En este caso, el inicio de la tendencia igualatoria se había producido fundamentalmente a raíz de la Ley 39/1999, de 5 de noviembre, para promover la conciliación de la vida familiar y laboral de las personas trabajadoras. El Estatuto, sin embargo, regula el contenido mínimo de estos derechos en su artículo 49 diseccionándolo en un haz de permisos, como el permiso por parto, adopción o acogimiento de dieciséis semanas ininterrumpidas, el permiso de 15 días por paternidad para esos mismos supuestos o el permiso por razón de violencia de género sobre la mujer funcionaria. Estos preceptos resultan directamente aplicables a todo el personal laboral, al menos con carácter de norma mínima y conforme se deriva de la propia dicción literal del precepto y de lo dispuesto en el artículo 51 del Estatuto ${ }^{12}$. Nada impediría, no obstante, que a través de la negociación colectiva pudieran mejorarse sustantivamente las condiciones de todos estos permisos. Asimismo, y para evitar bretes que en ocasiones se producen, no estaría de más aclarar que todos estos derechos deben resultar aplicables a todo el personal laboral contratado, ya lo sea con carácter temporal, fijo o con carácter indefinido, toda vez que los bienes y valores constitucionales que están detrás de estos derechos impedirían hacer una distinción en virtud únicamente de la nota de temporalidad de su relación. Mayores problemas herme-

11 Al regular la movilidad por traslado, dispone este precepto que las mujeres víctimas de violencia de género que se vean obligadas a abandonar el puesto de trabajo en la localidad donde venían prestando sus servicios, para hacer efectiva su protección o el derecho a la asistencia social integral, tendrán derecho al traslado a otro puesto de trabajo propio de su cuerpo, escala o categoría profesional, de análogas características, sin necesidad de que sea vacante de necesaria cobertura. Aún así, en tales supuestos la Administración Pública competente estará obligada a comunicarle las vacantes ubicadas en la misma localidad o en las localidades que la interesada expresamente solicite. Ello contrasta con el derecho establecido en el art. 40. 3 bis del Estatuto de los Trabajadores, con la redacción introducida en este aspecto por la Ley Orgánica 1/2004, de 28 de diciembre. Así, en el ámbito laboral, sólo se reconoce a la mujer trabajadora un derecho preferente a ocupar otro puesto de trabajo, del mismo grupo profesional o categoría equivalente, que la empresa tenga vacante en cualquier otro de sus centros de trabajo. La obligación de la empresa se reduce, pues, a comunicar a la trabajadora las vacantes existentes en dicho momento o las que se pudieran producir en el futuro.

12 Así lo ha interpretado también el Informe de la Secretaría General para la Administración Pública sobre la aplicación del art. 48 del Estatuto Básico del Empleado Público al personal laboral al servicio de las Administraciones Públicas, de 13 de noviembre de 2007. 
néuticos plantea, no obstante, la aplicación a este colectivo de los derechos laborales enumerados en el art. 48 del Estatuto Básico, tal como veremos más detenidamente en el epígrafe siguiente.

\section{La problemática aplicación de los permisos contemplados en el artículo 48 del Estatuto Básico. El recurso al principio de la norma más favorable y la «técnica del espigueo»}

El Estatuto Básico también contempla el régimen sustantivo y concreto de algunos de los derechos enumerados en el artículo 14 del Estatuto Básico. En estos casos puede decirse que se acrecientan todavía más los problemas interpretativos que plantea la integración de dos fuentes distintas: la ley administrativa y el convenio colectivo o, mejor dicho, la aplicación a este nuevo ámbito de los principios que rigen las relaciones entre la ley laboral y la negociación colectiva. Me refiero específicamente al principio de aplicación de la norma más favorable.

Los problemas surgen por la deficiente técnica jurídica empleada por el legislador estatutario en este concreto punto, que parece crear una aparente contradicción entre dos de sus preceptos. Mientras que el artículo 51 determina la aplicación directa a los laborales de lo dispuesto en el capítulo correspondiente al régimen de jornada de trabajo, vacaciones y permisos (artículos 47 a 50), los permisos recogidos en el artículo 48 parecen referirse única y exclusivamente a los funcionarios públicos. Al menos esa es la interpretación que deriva de su propia dicción literal, que menciona explícitamente por dos veces al colectivo funcionarial en vez de utilizar el nuevo concepto global de empleado público ${ }^{13}$.

Efectivamente, la técnica empleada por el legislador básico para concretar los permisos de naturaleza laboral presenta interesantes interrogantes. La primera cuestión que se puede plantear es la de determinar si el listado de permisos establecido en el artículo 48 del Estatuto para los funcionarios resulta también aplicable a los laborales de la Administración. Según el tenor literal del precepto, «las Administraciones Públicas determinarán los supuestos de concesión de permisos a los funcionarios públicos y sus requisitos, efectos y duración. En defecto de legislación aplicable los permisos y su duración serán, al menos los siguientes...». Pues bien, ante la dicción literal del precepto que, por cierto, hace que el legislador básico se convierta automáticamente en legislador subsidiario o supletorio, ¿podría decirse que los mismos resultan también aplicables de forma directa al personal laboral, incluso de forma preferente a la regulación que se haya podido establecer en el correspondiente convenio colectivo?

13 E incluso esa parece ser también la interpretación que ha realizado de una forma un tanto desconcertante el Ministerio de Administraciones Públicas a través del Informe de la Secretaría General para la Administración Pública sobre la aplicación del art. 48 del Estatuto Básico del Empleado Público al personal laboral al servicio de las Administraciones Públicas, de 13 de noviembre de 2007. 
Del Informe de la Dirección General de Función Pública sobre la aplicación del art. 48 del Estatuto Básico del Empleado Público al personal laboral al servicio de las Administraciones Públicas, de 13 de noviembre de 2007, parece deducirse inicialmente que el listado de permisos enumerado en dicho precepto resultaría aplicable exclusivamente al personal funcionarial. Para los laborales sólo sería directamente aplicable el régimen de permisos relacionados con la protección de bienes y derechos constitucionales establecidos en el art. 49. No obstante, en páginas posteriores del informe parece que se matizan estas primeras consideraciones iniciales al dejar abierta la posibilidad de que los permisos del art. 48 se apliquen directamente a los funcionarios y sólo supletoriamente a los laborales en caso de que no exista convenio aplicable. De existir convenio, se entendería que se aplicaría directamente lo dispuesto en éste, aunque los permisos fueran inferiores ${ }^{14}$.

A mi juicio, la extensión de los permisos del art. 48 directamente al personal laboral de la Administración parece la solución más lógica si tenemos en cuenta, en primer lugar, que es la equiparación de regímenes jurídicos la idea básica y la filosofía inspiradora de la nueva regulación en esta materia. En segundo lugar, que el artículo 51 del Estatuto aplica directamente al personal laboral en materia de jornada, permisos y vacaciones lo dispuesto en el capítulo V, sin excepcionar, pues, ningún concreto precepto. Donde la ley no distingue, no debemos distinguir. Por último, a la misma conclusión se llegaría analizando la técnica jurídica empleada por el legislador básico en dicho precepto, pues ciertamente ha querido configurar todo el listado de permisos de este precepto con carácter de «mínimos» y aplicables en defecto de legislación.

Ahora bien, una vez admitida la aplicabilidad de estos permisos al personal laboral se plantea otro interesante problema de integración de fuentes. ¿Se ha de aplicar en todo caso - y como preferente- el artículo 48 o los permisos contemplados en los convenios colectivos? ¿Y si éstos contemplan permisos menos favorables que los previstos en el Estatuto? Ello nos lleva a analizar el problema de la relación entre el Estatuto Básico y los convenios colectivos existentes y, más concretamente, la vigencia en este ámbito del principio de aplicación de la norma más favorable ${ }^{15}$. Las soluciones que al respecto se están

14 En los Criterios para la aplicación del Estatuto Básico del Empleado Público en el ámbito de la Administración Local se establecía textualmente que «los permisos del artículo 48 lo serán «en defecto de legislación aplicable». A tal efecto se entenderá por legislación aplicable los Acuerdos, Convenio u otros instrumentos negociales».

15 Dados los principios inspiradores en el ámbito laboral de las relaciones entre la norma y el convenio colectivo, en ocasiones, no sólo se tiende a aplicar la condición más favorable para el trabajador, sino que incluso se intentan realizar interpretaciones más beneficiosas que las expresamente previstas en el texto de la norma o del convenio. Buen ejemplo de ello podemos encontrar en la STS de 20.01.09 (Sala de lo Social), que ha tenido que recurrir a los principios que rigen la actividad administrativa para intentar poner freno a este tipo de prácticas. En este caso concreto, se pretendía una interpretación extensiva de un Decreto valenciano que, con ocasión de compatibilizar la vida personal y laboral, había previsto que la reducción en una hora diaria de trabajo del personal laboral no supondría una reducción proporcional de la retribución. El 
encontrando son completamente dispares. Mientras que en muchas Administraciones Locales no se plantea siquiera la aplicación de los permisos del nuevo precepto, en otras se solicita el disfrute sólo de aquellos concretos permisos del Estatuto que resultan más ventajosos que los previstos en el convenio colectivo aplicable. Significativa resulta, en este sentido, la judicialización de que está siendo objeto el permiso relativo a los días de libre disposición, esto es, a los famosos «moscosos» que hacen honor al nombre del Ministro que los instituyó para los funcionarios públicos.

Los primeros pronunciamientos judiciales que se están produciendo tampoco contribuyen mucho a clarificar el problema. Voy a poner dos ejemplos que, aunque llegan a la misma solución práctica (aplicación final del régimen más favorable y ventajoso para el laboral), lo hacen a través de caminos diferentes. En el primer caso, a través de la aplicación del principio de norma más favorable y, en el segundo, a través de la matización de dicho principio y mediante el recurso a la prohibición de la técnica del espigueo. Veámoslas.

Como ejemplo del primer supuesto podemos traer a colación la STSJ del País Vasco, de 7 de octubre de 2008, Sala de lo Social, (AS 2008\2693), que ha reconocido al personal laboral de un Ayuntamiento vasco el derecho a disfrutar de los seis días retribuidos por asuntos propios contemplados en la letra k) del art. 48 del EBEP, a pesar de que su convenio colectivo sólo había previsto dos días. En concreto, ha considerado dicha sentencia que:

...«El citado artículo 48 contiene una expresión, «legislación», que ha de ser considerada en su acepción estricta, relacionando sistemáticamente el contenido exegético de tal concepto con el de otra fuente de la relación laboral: la que se fija en el artículo 3 punto 1 letra a del Estatuto de los Trabajadores: las disposiciones legales, no los convenios colectivos. En efecto, la misma jurisprudencia que señala aquella naturaleza doble o mixta del convenio colectivo, señala también que el mismo ha de atener al derecho necesario fijado por Ley, no pudiendo soslayarlo o infringirlo. La Sentencia de la Sala Cuarta del TS de 24 de noviembre de 2003, sintetiza tales ideas al decir: «En el a veces difícil equilibrio entre la Ley y el convenio, parece claro que la Ley, de carácter necesario - e incluso el Reglamento del mismo carácter- debe predominar sobre las normas paccionadas, en el sentido de que estas no pueden establecer condiciones menos beneficiosas para los trabajadores que las legales». A partir de ahí, considera la sentencia que el «artículo 37.1 de la Constitución no se vulnera por la entrada en vigor de una Ley que repercuta sobre los convenios colectivos que estén entonces vigentes. Aunque la negociación colectiva descanse y se fundamente en la

sindicato había solicitado una extensión de dicho privilegio a las reducciones de jornada que excedieran de una hora. Pues bien, ante dicha situación entiende el Tribunal que la retribución del trabajo se rige por el principio de reciprocidad o correspondencia con el trabajo prestado, que impide reconocer descansos o tiempos de inactividad remunerados distintos de los previstos en las disposiciones reguladoras de las condiciones de vida y trabajo. Asimismo, ha insistido en que tampoco se pueden perder de vista las razones de «eficacia» en la gestión del empleo público que, según el art. 103.1 de la Constitución, han de inspirar la actuación de las Administraciones Públicas. 
Constitución (artículo 37.1), de esta misma se deriva la mayor jerarquía de la Ley sobre el convenio, como se desprende de su artículo 7, que sujeta a los destinatarios del mismo, sindicatos de trabajadores y organizaciones empresariales, a lo dispuesto en la ley».

Al haberse previsto la aplicación del artículo 48 sólo en defecto de legislación aplicable, ha entendido esta línea jurisprudencial que el legislador básico no se estaría refiriendo a los convenios colectivos, sino exclusivamente a aquellos casos en que no existan normas legales de desarrollo de dicha normativa básica o «de mínimos» que el nuevo Estatuto del Empleado Público instaura. Es decir, esta sentencia ha interpretado que el convenio colectivo que dispone permisos en peores condiciones que las contempladas en este precepto quedaría desplazado. Nos encontraríamos, en consecuencia, con un convenio colectivo laboral vigente cuya eficacia es alterada y modificada por el contenido del Estatuto Básico, en la medida en que contempla en este aspecto una norma más favorable para los trabajadores de la Administración.

Por el contrario, la Sala de lo Social de la Audiencia Nacional, en una Sentencia de 25 de enero de 2008 , se ha pronunciado en un sentido diferente y bastante más matizado al pronunciarse sobre la incidencia que ha tenido la entrada en vigor del Estatuto Básico en los días de libre disposición que contemplaba el convenio colectivo de la Entidad Pública Empresarial Aeropuertos Españoles y Navegación Aérea (AENA). La Unión Sindical Obrera planteó un conflicto colectivo que versaba sobre la aplicabilidad de los días de libre disposición reconocidos con carácter de norma mínima en el artículo 48 del Estatuto Básico a los más de diez mil trabajadores que el citado organismo tiene repartidos en todo el territorio nacional. Al respecto, la Sala ha matizado considerablemente el principio de la aplicación de la norma más favorable con la prohibición de la denominada «técnica del espigueo». La superposición simultánea de dos fuentes de derecho se resuelve, a juicio de la Sala, en el artículo 3.3 del Estatuto de los Trabajadores en razón de aplicabilidad del principio de norma más favorable apreciada en su conjunto y en cómputo anual, respecto de los conceptos cuantificables. A tal efecto, «esa consideración global impide el uso de la "técnica del espigueo", que consiste en romper la indivisibilidad interna del precepto (ley o convenio) anulando su equilibrio interno, fruto del consenso entre los interlocutores sociales generadores de la norma, eligiendo de una u otra fuente de derechos aquellos preceptos aislados que pudieran mejorar los de la otra fuente y los preceptos de ésta que mejoran aquella».

En este caso, la solución final pasa por la declaración de aplicación preferente del convenio colectivo porque, en cómputo global, su régimen era más beneficioso que el resultante de la suma de días de permisos y vacaciones del Estatuto Básico. Así, argumenta la Sala que para determinar la aplicación global de la norma más favorable habrán de tenerse en cuenta ambos bloques cerrados como conjuntos comparables, sin posibilidad de fracturas parciales o 
«espigueos», de las disposiciones que integran ambos: los permisos y vacaciones del convenio colectivo de AENA y los permisos y vacaciones del Estatuto Básico. En este caso, la Sala llega a la conclusión de que aplicando el convenio citado, las vacaciones y permisos del trabajador alcanzan los 35 días, mientras que si se aplica el Estatuto Básico, el trabajador alcanzaría sólo 33 días, y ello partiendo de una antigüedad de 24 años de servicio, porque hasta entonces la diferencia sería aún mayor.

En definitiva, pues, el cóctel de las dificultades exegéticas que plantea la técnica jurídica empleada por el legislador en esta materia con los problemas interpretativos que de por sí ya plantea la integración de dos fuentes distintas (el Estatuto Básico y los convenios colectivos), no hace sino crear un complejo marco de incertidumbre jurídica acerca del régimen aplicable a los permisos del personal laboral, que es especialmente inquietante en el ámbito de la Administración Local por las situaciones tan dispares que pueden encontrarse y el riesgo de discriminación que ello entraña.

\section{La exclusión del derecho a la inamovilidad como una cuestión más teórica que de efectos prácticos}

La inamovilidad en la condición de funcionario de carrera es el único derecho que no se ha querido extender al personal laboral de la Administración y que, en consecuencia, permite establecer una diferencia esencial, al menos desde el punto de vista teórico, entre los funcionarios y los contratados laborales. En su exclusión, a mi juicio, ha de verse el deseo del legislador de seguir manteniendo una de las notas más características de la figura funcionarial y que justificó que se fuera gestando durante todo el siglo XIX un régimen para los funcionarios de la Administración completamente distinto del aplicable al resto de trabajadores de una empresa privada.

Efectivamente, desde el Estatuto de O’Donnell (Real Decreto de 4 de marzo de 1866 por el que se aprueba el Reglamento orgánico de las carreras civiles de la Administración Pública) puede decirse que la inamovilidad comenzó a constituir el rasgo distintivo esencial entre funcionarios y trabajadores. Dicho texto, aunque seguía básicamente las líneas generales establecidas por el Estatuto de Bravo Murillo, tuvo el mérito de reconocer por vez primera el instituto de la inamovilidad de los funcionarios públicos, aunque con una nada desdeñable limitación que consistía en aplicarla únicamente en relación con el número de años de servicio efectivo prestados por los funcionarios ${ }^{16}$. La inamovilidad su-

16 El Reglamento de O`Donnell tuvo una vigencia muy reducida, tan sólo durante cuatro meses, puesto que el 13 de julio de 1866, siendo Narváez Presidente del Consejo de Ministros, se aprobó un Real Decreto derogador de aquel reglamento. Narváez pretendía que la potestad de nombrar y separar libremente a los empleados quedara intacta. Se entra así en un período de importantes convulsiones políticas que va a acentuar la inestabilidad propia de los empleados públicos al considerarse el cargo y el empleo como uno de los más 
ponía para los funcionarios públicos lograr la estabilidad en el desempeño de sus funciones, frenando las continuas injerencias tanto del Monarca como del Gobierno de turno de que eran objeto los funcionarios. En la medida en que suponía una victoria para los empleados públicos frente a la habitual práctica de separarlos del servicio sin la concurrencia de ninguna causa justificada, fue considerada como un importantísimo privilegio respecto al resto de trabajadores sometidos al Derecho privado, por lo que rápidamente empezó a configurarse como uno de los elementos más distintivos entre ambos regímenes jurídicos.

Pues bien, la necesidad de mantener esta nota como una característica exclusiva del régimen funcionarial fue puesta de manifiesto por el Informe del Comité de Expertos, no sólo por razones históricas, sino también y fundamentalmente por motivos objetivos, toda vez que constituye un aspecto esencial para garantizar la imparcialidad del funcionario público en el ejercicio de sus funciones ${ }^{17}$. Aunque se insistía en la necesidad de no considerar esta institución como un privilegio, ciertamente hoy en día habría que interpretarlo desde unas claves muy distintas, pues evidentemente las razones históricas que justificaron esta figura han desaparecido. Su mantenimiento habría de justificarse principalmente en la necesidad de garantizar los principios de objetividad y de eficacia de la actuación administrativa (art. 103.1 de la Constitución), así como en el establecimiento de las garantías para la imparcialidad del funcionario que menciona el art. 103.3 de la Constitución, que quedarían seriamente comprometidos sin la nota de estabilidad que implica esta figura.

A partir de esta lectura constitucional, podría incluso ponerse en tela de juicio la decisión del legislador de excluir este derecho al personal laboral ${ }^{18}$. Si lo que se persigue es garantizar la objetividad y eficacia de la Administración, esta nota habría de predicarse de todo su personal, con independencia de la naturaleza del vínculo que les mantiene unido a la Administración. En todo caso, ello no significa que el personal laboral no pueda ni deba ser imparcial. Más bien podría decirse que

ansiados botines políticos. Esta última norma ha sido considerada como uno de los ejercicios más depurados del cinismo político que puedan verse en el siglo pasado. MARTínEZ DE PISÓN APARICIO, Iñigo, «La inamovilidad de los funcionarios públicos en medio siglo de producción normativa: régimen general de los funcionarios entre 1852 y 1900», Anuario Jurídico y Económico Escurialense, 1989-1990, pág. 96.

17 Tal como describió GARCíA DE ENTERRÍA, durante todo el siglo XIX, «el funcionario era el botín del partido vencedor; el principio constitucional que definía el nombramiento de los empleos públicos como prerrogativa del Ejecutivo, fue sistemáticamente invocado, lo que de hecho permitía (e incluso determinaba) la ausencia de una Administración verdaderamente construida y fuerte». GARCÍA DE ENTERRÍA, Eduardo, «La fonction publique en Espagne», Annuaire International de la Fonction Publique, París, 1974-1975, págs. 198-199.

18 Linde PANiaguA, Enrique, en «Derechos, deberes y obligaciones de los empleados públicos desde la perspectiva de desarrollo de los mismos», en la obra colectiva dirigida por él mismo, titulada El Estatuto Básico del Empleado Público y su desarrollo por el Estado y las Comunidades Autónomas, Colex, Madrid, 2008, págs. 83 y 84, considera que no existe ningún inconveniente para que el legislador no básico pueda extender el derecho a la inamovilidad a los empleados laborales, en particular, a los que están vinculados a las Administraciones Públicas con contratos calificados como fijos o por tiempo indefinido. No obstante, a nuestro juicio, la extensión de esta garantía a los contratados indefinidos no haría sino contradecir el nuevo régimen jurídico que caracteriza a esta figura. 
el legislador ha querido ser coherente con las funciones que está llamado a desempeñar cada uno de estos colectivos, pues las más importantes tareas administrativas, las que están relacionadas directa e indirectamente con el ejercicio de funciones de autoridad y con la salvaguardia de los intereses generales, han sido reservadas en exclusiva a quienes ostenten la condición de funcionario público (art. 9.2 del Estatuto Básico del Empleado Público). Como resulta evidente, el ejercicio concreto de este tipo de tareas requiere intensificar al máximo la imparcialidad del funcionario, con todas las cautelas y garantías que sean necesarias para ello.

Por otra parte, y al margen de esta justificación teórica, habría que tener en cuenta que en la práctica no son tantas las diferencias que existen entre los funcionarios y los laborales en cuanto a la permanencia o estabilidad en el empleo, a tenor de lo que se deduce de alguna de las novedades introducidas por el nuevo Estatuto Básico. Por una parte, efectivamente, se ha difuminado significativamente la nota de permanencia en el puesto que tradicionalmente se ha anudado a la inamovilidad. Ha quedado acreditado que la inamovilidad del funcionario no lo es en el cargo, toda vez que la permanencia en un concreto puesto de trabajo - obtenido incluso por concurso - va a quedar directamente subordinada a la previa evaluación positiva del funcionario (art. 20.4 del Estatuto) y condicionada por las necesidades objetivas y funcionales del servicio (art. 81.2). El derecho a la inamovilidad no es, por tanto, un derecho absoluto ${ }^{19}$. Significa que ningún funcionario podrá ser privado de su condición si no es mediante la sanción de separación de servicio por falta muy grave y a través del correspondiente expediente contradictorio.

Pues bien, desde esta perspectiva puede decirse que esta prerrogativa apenas difiere de la que disfruta en la actualidad el personal laboral fijo. Por una parte, al unificar el régimen disciplinario, el nuevo Estatuto Básico ha extendido a este colectivo todas las garantías que implica el régimen sancionador, impidiendo la posibilidad de que pueda ser despedido de forma arbitraria por la Administración. Por otra, ha desaparecido la institución del despido improcedente o sin causa, pues, el artículo 96.2 del Estatuto dispone la readmisión automática del personal laboral fijo cuando sea declarado improcedente el despido acordado como consecuencia de un expediente disciplinario por la comisión de una falta muy grave. Es más, la jurisprudencia ha extendido este privilegio también para el personal indefinido. La STS de 2 de febrero de 2009 (Sala 4. ${ }^{a}$ ), ha estimado el recurso de casación para la unificación de doctrina y ha anulado la sentencia impugnada que condenaba a un Ayuntamiento a optar entre la readmisión del empleado o el abono del salario de tramitación ante un despido que había sido declarado improcedente, todo ello porque el convenio colectivo aplicable al personal laboral de dicho Ayuntamiento reconocía este derecho de opción a favor de todo empleado que tuviera un «contrato indefinido, fijo laboral o fijo discontinuo». Ha recurrido el Tribunal al principio de norma más favora-

19 SÁnchez Morón, Miguel, Derecho de la Función Pública, Tecnos, Madrid, 2008, págs. 206 y 207. 
ble y, en consecuencia, ha aplicado el convenio con preferencia respecto de lo establecido en el art. 96.2 del Estatuto Básico, al entender que le otorgaba unas garantías superiores. Pretender la aplicación del precepto a sólo los trabajadores fijos, a juicio de la Sala, deja sin sentido la alusión a los que tengan contrato indefinido, «categoría de creación jurisprudencial para los servidores de las administraciones públicas cuyos despidos son declarados improcedentes. No es óbice a lo anterior el mandato del art. 96.2 del Estatuto Básico del Empleado Público aprobado por la Ley 7/2007, de 12 de abril. Ese precepto, en su último párrafo, dispone que "procederá la readmisión del personal laboral fijo cuando sea declarado improcedente el despido como consecuencia de la incoación de un expediente disciplinario", pues tal regla, de carácter general, queda sin efecto cuando un convenio colectivo disponga lo contrario, al remitirse el art. $7 \mathrm{de}$ esa Ley a la legislación laboral en general».

En definitiva, pues, aunque el derecho a la inamovilidad en la condición del funcionario se consagra únicamente para el personal funcionarial, desde el punto de vista práctico se han difuminado considerablemente las diferencias que en otro tiempo ha supuesto esta garantía entre ambos colectivos.

\section{El reconocimiento del derecho a la promoción interna y a la «progresión en la carrera profesional». Algunas pautas para su desarrollo en la Administración Local}

La letra c) del art. 14 consagra el derecho de todos los empleados públicos a la progresión en la carrera profesional y a la promoción interna según los principios constitucionales de igualdad, mérito y capacidad, mediante la implantación de sistemas objetivos y transparentes de evaluación. Es decir, se reconoce como derecho de los laborales el establecimiento de un conjunto ordenado de expectativas de progreso dentro de la Administración en la que prestan sus servicios.

Aunque posteriormente el art. 19 del Estatuto concreta este derecho para el personal laboral, su importancia es enorme en la medida en que viene a consagrar de forma expresa, de una parte, la aplicación de los principios constitucionales que rigen el acceso a la Administración también a la carrera profesional y a la promoción profesional de los laborales de la Administración, tal como ya venía haciendo la jurisprudencia, y, por otra, establece la necesidad de implantar sistemas de evaluación, lo que supone una concepción nueva de la carrera profesional que abre nuevas e interesantes expectativas para los laborales. En este ámbito pues, todo el régimen ha de estar inspirado en unos principios (igualdad, mérito y capacidad) que no rigen en el ámbito laboral privado y debe efectuarse a través de la implantación de sistemas objetivos y transparentes de evaluación que pueden o no existir en el ámbito privado, pero que necesariamente ha de aplicar la Administración a todo su personal, independientemente 
de su naturaleza laboral o funcionarial. Así se deduce del régimen previsto para la nueva institución estrella del Estatuto Básico como es la evaluación del desempeño, toda vez que, según lo dispuesto en su art. 20, su implantación es una obligación para todas ellas: «las Administraciones Públicas establecerán sistemas que permitan la evaluación del desempeño de sus empleados».

El establecimiento de sistemas objetivos para medir y valorar la conducta profesional y el rendimiento o logro de resultados del trabajador resulta, en consecuencia, preceptivo para cada una de las Administraciones Locales, que deberán además, determinar los efectos que dicho instrumento puede producir en la carrera horizontal, en las retribuciones complementarias, en la formación y en la provisión de puestos $^{20}$. La Administración, no obstante, dispondrá de libertad a la hora de concretar dichos efectos, pues el único que viene predeterminado por el Estatuto con carácter imperativo es el relativo a la continuidad en el puesto de trabajo. La evaluación negativa podrá dar lugar al cese del empleado en su puesto, previa audiencia al interesado y a través de la correspondiente resolución motivada. Significa ello que, aunque la instauración de la evaluación del desempeño no obliga en modo alguno al establecimiento de un determinado modelo de carrera horizontal, sí resulta imprescindible para poder establecer éste.

Pues bien, en nuestro análisis hemos de partir necesariamente de lo dispuesto en el art. 19 del Estatuto Básico, que se limita a proclamar que «el personal laboral tendrá derecho a la promoción profesional. La carrera profesional y la promoción del personal laboral se hará efectiva a través de los procedimientos previstos en el Estatuto de los Trabajadores o en los Convenios colectivos». La mera lectura literal de este precepto puede conducir a equívocos si no se tiene en cuenta su contexto, pues parece remitirse sin más al régimen general de fuentes de los trabajadores, lo cual no es del todo exacto en el ámbito de la Administración, tal como hemos venido apuntando desde las primeras páginas de este trabajo. Lo conveniente, a mi juicio, es hacer una lectura integradora de las instituciones y posibilidades que contempla el articulado del Estatuto Básico a la hora de desarrollar toda esta materia.

\section{A) La promoción profesional. Especial referencia a la promoción cruzada prevista en la Disposición Transitoria Segunda del Estatuto Básico}

En el ámbito laboral, el art. 24 del Estatuto de los Trabajadores sólo prevé los ascensos como la principal institución que permite al trabajador obtener una progresión laboral, su promoción profesional. Aunque esta ley no proporciona ninguna definición jurídica de lo que haya de entenderse por ascenso, esta figura

20 Para profundizar sobre este tema nos remitimos a GORRITI BONTIGUI, Mikel, y LÓPEZ BASTERRA, Joseba, Identificación de criterios de desempeño a partir del análisis de puestos, IVAP, Oñati, 2009 
no puede entenderse al margen del sistema de clasificación profesional (categorías o grupos, según lo dispuesto en su art. 22) e implica un cambio a una función profesional superior a la que el trabajador lleva a cabo en el marco de su relación laboral. Así concebido, el ascenso implica la ocupación por parte del trabajador de una categoría superior a la que hasta ese momento venía ostentando.

Aunque depende de lo dispuesto en cada convenio, suele establecerse un sistema de clasificación, que normalmente se estructura en grupos profesionales, áreas funcionales, categorías y en su caso especialidades, que se utilizan, no sólo para favorecer la promoción del personal laboral estableciendo para ello mecanismos de carrera dentro del sistema, sino también con el fin de facilitar su movilidad funcional e interdepartamental. El grupo profesional suele agrupar las titulaciones y el contenido general de la prestación laboral que se corresponde con las mismas. Las áreas funcionales se utilizan para agrupar dentro de cada grupo profesional el conjunto de contenidos y tareas que por su naturaleza se encuadran dentro de una determinada profesión, oficio o rama de actividad profesional. Por el contrario, la categoría profesional se define por su pertenencia a un grupo profesional y área funcional y suele recoger de manera no exhaustiva las actividades propias de las mismas, de acuerdo con la organización y ordenación de los procesos de trabajo.

A partir de ahí, la única posibilidad de promoción profesional que se recoge en la normativa laboral es el ascenso, cuyo equivalente en el ámbito de la Administración sería la denominada promoción profesional. Lo lógico es que la Administración convoque mediante un turno restringido de promoción interna los puestos de trabajo vacantes no cubiertos por otros turnos y que sólo se permita participar en este turno a los trabajadores fijos del grupo profesional inmediatamente inferior que posean determinados requisitos, de forma similar a lo que ocurre con la promoción interna de los funcionarios. Así, es frecuente que se exija una antigüedad mínima de dos años de servicios efectivos en dicho grupo profesional, el cumplimiento de los requisitos de titulación y cualificación exigidos, así como la necesaria superación de pruebas específicas correspondientes a las funciones propias de la actividad, aunque todo dependerá, en última instancia, de lo que prevea el convenio colectivo negociado en el ámbito de cada Administración Local.

En definitiva, tal como entiende la doctrina laboralista, sea más o menos flexible el sistema de clasificación de la empresa, en cualquier caso, en el ascenso se producirá siempre una modificación de las funciones que el trabajador debe realizar. Las nuevas expectativas que, a mi juicio, abre el Estatuto Básico en este punto, serían interesantísimas en la medida en que permitiría la posibilidad de que en los convenios colectivos se pueda pactar un modelo de carrera horizontal, esto es, que permita la progresión del laboral sin necesidad de cambiar de puesto de trabajo. De ello, no obstante, nos ocuparemos en el epígrafe siguiente.

Por otra parte, el Estatuto Básico abre nuevas perspectivas también para el diseño de la promoción interna e incluso regula directamente algunos supues- 
tos. Así, la Administración Local deberá valorar el papel que puede jugar la evaluación del desempeño también para configurar el régimen de promoción profesional que finalmente negocie para su personal laboral. De hecho, no es del todo impensable que la evaluación positiva del laboral pueda ser establecida como un requisito de participación para la promoción a determinados puestos de trabajo o que, en todo caso, sea considerada como un mérito en los correspondientes procedimientos que se establezcan para la promoción profesional. En otras ocasiones, el legislador ha previsto el régimen de alguna de las modalidades que admite la promoción. Me refiero a los procesos de funcionarización que contempla su disposición transitoria segunda, pues no son sino una modalidad de promoción interna cruzada.

Esta disposición contempla una habilitación legal para que el personal laboral que resulte afectado por la nueva de reserva de funciones establecida para los funcionarios públicos en el art. 9.2 del Estatuto pueda seguir desempeñando sus mismos puestos. La habilitación, no obstante, no abarca al personal laboral temporal ni al indefinido, pues dado el carácter temporal de su vínculo con la Administración, la regularización podrá venir por otras vías. Está limitada únicamente al personal laboral que reúna la condición de fijo en el momento de entrada en vigor del Estatuto (13 de mayo de 2007) o pase a desempeñarlas en virtud de pruebas de selección o promoción convocadas antes de dicha fecha ${ }^{21}$. Estos procesos de funcionarización se canalizan a través de la denominada promoción interna cruzada, pues contemplan la posibilidad de que el laboral afectado pueda regularizar su situación y funcionarizarse mediante su participación en los correspondientes procesos selectivos de promoción interna y a través del sistema de un concurso-oposición. En realidad se trata de un sucedáneo del sistema de promoción cruzada que permite el cambio en la naturaleza jurídica del vínculo, el paso de la condición de laboral a la condición funcionarial, sin necesidad de cumplir el requisito de los dos años de antigüedad en el puesto que exige el nuevo artículo 18.2 del Estatuto, así como el artículo 22.3 de la Ley de Medidas, que todavía sigue vigente. Para ello se tendrán en cuenta las pruebas selectivas que el laboral tuvo que superar para acceder a esta condición, con lo cual se evita que se repitan pruebas relativas a conocimientos y capacidades que en su día ya resultaron suficientemente acreditados en el oportuno procedimiento selectivo de acceso. Asimismo, se valorarán como mérito los servicios efectivos prestados como personal laboral fijo siempre que ello no suponga una diferenciación irrazonable, desproporcionada o arbitraria; es decir, siempre que la valoración del tiempo de

\footnotetext{
21 La mención expresa de aplicación de esta Disposición también a los laborales que se encuentren inmersos en procesos de selección o promoción interna antes de la entrada en vigor de la ley resulta lógica si tenemos en cuenta la interpretación restrictiva que de los requisitos han realizado algunas sentencias. Así, por ejemplo, la SAN de 7 de febrero de 2006, ha desestimado la solicitud de un trabajador laboral de permitir el acceso a las correspondientes pruebas selectivas convocadas para la integración porque, aunque en el momento de la convocatoria poseía la condición de laboral fijo, no la ostentaba en el momento de entrada en vigor de la Ley habilitante.
} 
servicios prestados con anterioridad no se convierta en «título de legitimación exclusivo que permita el acceso a una función pública de carácter permanente» (STC 27/1991, de 14 de febrero).

Estos procedimientos podrán ser convocados por la Administración de forma independiente o conjunta con los procesos selectivos de libre concurrencia y permitirán el acceso del laboral a aquellos Cuerpos y Escalas a los que figuren adscritos las funciones o los puestos que desempeñe. Es requisito para ello, como resulta lógico, que el laboral posea la titulación necesaria para la ocupación del puesto funcionarial así como los restantes requisitos exigidos en la convocatoria, aunque están exentos del requisito de poseer una antigüedad de al menos dos años en el puesto desde el que se va a promocionar. Conviene tener en cuenta que de la lectura de este precepto no se infiere la configuración de procedimientos selectivos restringidos y limitados únicamente al personal afectado por esta Disposición, sino meramente a la posibilidad ya existente de que las pruebas de promoción interna se puedan llevar a cabo en convocatorias independientes de las de nuevo ingreso, como viene siendo ya práctica habitual durante los últimos años ${ }^{22}$. Por ello, en los procedimientos selectivos de promoción interna para la ocupación de las plazas funcionarizadas podrá concurrir cualquier otro funcionario o laboral siempre que cumpla todos los requisitos generales de antigüedad y titulación que el artículo 18.2 del Estatuto o las correspondientes convocatorias en su caso puedan establecer. Y ello porque sólo dicha interpretación puede resultar compatible con el artículo 23.2 y 103.3 de la Constitución, así como con la interpretación que la doctrina constitucional ha realizado de dichos preceptos.

Efectivamente, la STC 27/1991, de 14 febrero, en relación con la posibilidad de establecer pruebas específicas a las que sólo tienen acceso determinados colectivos de personal, estableció que «es evidente que el derecho a la igualdad en el acceso a la función pública supone una limitación, fundamentada en la práctica de las llamadas pruebas restringidas para el acceso a la función pública, las cuales, en general, han de considerarse como un procedimiento proscrito en el art. 23.2 de la CE, si bien no cabe excluir que, en determinados casos excepcionales, la diferencia de trato establecida en la Ley en favor de unos y en perjuicio de otros pueda considerarse como razonable, siempre que dicha diferenciación se demuestre como un medio excepcional y adecuado para resolver una situación también excepcional, expresamente prevista en una norma con rango de ley y con el objeto de alcanzar una finalidad constitucionalmente legi-

\footnotetext{
22 Es más, podría aquí traerse a colación la doctrina fijada en la STC 16/1998, de 26 de enero, en cuya virtud, la específica alusión a que se valoren como méritos los servicios prestados podría hacer pensar que la norma está pensando en una convocatoria libre, no restringida, toda vez que «estos méritos adquieren relevancia sobre todo respecto de aquellos que no se encuentran en esta situación». En un sentido similar puede consultarse la STC 38/2004, de 11 de marzo.
} 
tima, entre las que se integra también la propia eficacia de la Administración Pública $^{23} \gg$.

Por otra parte, conviene recordar que no puede ser fruto de la negociación el establecimiento de procesos de funcionarización distintos a los expresamente previstos en esta Disposición. No cabría, por ejemplo, que a través de un convenio colectivo se pudiera extender este proceso al personal laboral indefinido o contratado. Así, podría traerse a colación la STS de 28 de julio de 2006, que ha declarado la ilegalidad de un Acuerdo celebrado por la Diputación Provincial de Granada en la medida en que suponía una infracción de la Disposición Transitoria Decimoquinta de la Ley 30/84, pues ampliaba el proceso de funcionarización a un colectivo de personal laboral de la Diputación más amplio que el regulado en aquélla. El Acuerdo reconocía este proceso a cualquier laboral que se encontrara en la situación de desempeñar puestos reservados a funcionarios «a la entrada en vigor de este Acuerdo» y no lo circunscribía al contingente de personal laboral más reducido que establecía la mencionada disposición: al personal laboral fijo que, a la entrada en vigor de la Ley 23/1988, de 28 de julio, se hallare prestando servicios en puestos de trabajo reservados a funcionarios. Y ello porque no sólo han de respetarse los requisitos profesionales, de titulación y de puesto desempeñado que han de ser reunidos por quienes aspiren a ese acceso, sino también ha de observarse ese límite temporal que la ley establece en orden a la situación especial que toma en consideración para permitir el singular acceso del que se viene hablando.

\section{B) Algunas consideraciones sobre la posibilidad de introducir un modelo de carrera horizontal también para el personal laboral. Sus premisas}

La aplicación al ámbito laboral de la terminología utilizada en el art. 19 del Estatuto Básico plantea ciertas dificultades por la falta de coincidencia de los términos, lo que nos demuestra, una vez más, que estamos ante una materia completamente publificada o administrativizada. En el ámbito funcionarial, y en el modelo de la Ley 30/84, se distinguía entre promoción profesional y promoción interna ${ }^{24}$. En la promoción profesional, o lo que antes podíamos deno-

\footnotetext{
23 A mayor abundamiento, la STC 16/1998, de 26 de enero, aclaró todavía más esta posición doctrinal sistematizando sus requisitos. Es preciso, «primero, que se trate de una situación excepcional; segundo, que sólo se acuda a este tipo de procedimientos una sola vez, pues de otro modo se perdería su condición de remedio excepcional para una situación también excepcional y, en tercer y último lugar, que dicha posibilidad esté prevista en una norma de rango legal». Para profundizar nos remitimos a BOLTAINA BosCH, Xavier, en $\mathrm{La}$ Funcionarización del personal laboral al servicio de las Administraciones Públicas, Cedecs, 2005.

24 La promoción interna se concibe como el ascenso a un grupo de titulación inmediatamente superior mediante las correspondientes pruebas selectivas, aunque cabían otros sistemas de promoción interna horizontal (para cuerpos pertenecientes al mismo grupo de titulación) y cruzada (que permitía el acceso de los laborales a puestos semejantes funcionariales).
} 
minar como «carrera administrativa», todo el sistema se articulaba en torno a la idea de clasificar los puestos de trabajo en treinta niveles y atribuir a cada funcionario un grado personal, como consecuencia del desempeño de uno o más puestos del mismo nivel durante dos años continuados o tres con interrupción. La carrera, en este sistema, consistía en la obtención de un nuevo puesto de trabajo que tuviera asignado un grado o nivel mayor ${ }^{25}$. Este modelo de carrera, sin embargo, ha generado numerosas disfunciones, en la medida en que ha convertido al funcionario en un «peón saltarín» que necesita cambiar continuamente de puesto. El acceso a un puesto de trabajo que tenga atribuido un mayor nivel es la única manera que encuentra para hacer carrera, en la medida en que al menos obtendrá el progreso económico inmediato que supone ver incrementada su nómina con el nuevo complemento de destino. Con ello, sin embargo, se desaprovecha por completo la experiencia adquirida por el desempeño de las tareas de su puesto, se genera un enorme esfuerzo para la Administración, que se ve obligada a realizar continuos concursos para permitir esta movilidad, a la vez que se ha generado un importantísimo problema de inflación orgánica sin que existan, en la mayoría de los casos, reales causas organizativas que lo justifiquen. Este problema es especialmente gravoso en el ámbito de la Administración Local, especialmente en las Entidades más pequeñas, donde apenas existen puestos de trabajo para poder moverse y por tanto es prácticamente imposible que el funcionario pueda hacer carrera.

Pues bien, ante todos estos problemas, la gran aportación del Estatuto Básico en esta materia ha sido la de permitir que las Administraciones puedan instaurar un modelo de carrera que se desvincule de la ocupación de puestos de trabajo, de un modelo de carrera horizontal. En este sentido, recoge por vez primera una definición de lo que haya de entenderse por carrera, definiéndola como el conjunto ordenado de oportunidades de ascenso y expectativas de progreso profesional conforme a los principios de igualdad, mérito y capacidad, de modo que la carrera o promoción profesional se ha de abordar como un itinerario de avance o crecimiento profesional que debe ofrecer expectativas de progresión. A su vez, permite la posibilidad de que puedan establecerse dos modelos de carrera, la vertical y la horizontal. Para los funcionarios públicos serán las leyes de desarrollo del Estatuto las que concreten qué tipos de carrera habrá y cuál será su diseño de conformidad con lo establecido por el legislador básico. Para los laborales será nuevamente el convenio colectivo el instrumento que establezca el modelo de carrera o promoción profesional, pues el Estatuto no contempla un

25 Aunque empieza a ser ya muy abundante la bibliografía sobre el tema de la carrera profesional, para profundizar sobre el tema nos remitimos al clásico estudio de ARROYO YANES, Luis Miguel, La carrera administrativa de los funcionarios públicos, Tirant lo Blanch, Valencia, 1994; a FÉREZ FERNÁNDEZ, Manuel, La carrera administrativa: nuevas perspectivas, Editado por la Diputación de Barcelona, septiembre de 2006 y «Derecho a la carrera profesional y a la promoción interna (arts. 16 a 19), en la obra colectiva titulada Comentarios al Estatuto Básico del Empleado Público, dirigida por Salvador DELL ReY GUANTER, La Ley, 2008, págs. 269 y ss.; a FUENTETAJA PASTOR, Jesús Ángel, «Estatuto Básico y Carrera Funcionarial» en la obra colectiva coordinada por Enrique Linde PANIAGUA, El Estatuto Básico del Empleado Público y su desarrollo por el Estado y las Comunidades Autónomas, Colex, Madrid, 2008, págs. 155 y ss. 
régimen desarrollado, ni siquiera apuntado, de carrera para este personal. $\mathrm{Su}$ concreción se limita a una mera afirmación de que la misma se hará efectiva a través de los instrumentos que proceden de la negociación colectiva ${ }^{26}$.

Ciertamente el diseño de un modelo de carrera en la Administración Local no resulta cuestión fácil, al ser ésta una institución muy compleja y conflictiva, en la medida en que, además de ser configurada como un derecho de los empleados públicos, la carrera no deja por ello de ser una institución y un subsistema de gestión de personas. Como ha apuntado Manuel Férez ${ }^{27}$, lograr un equilibrio entre estas dimensiones crea una tensión permanente entre los intereses organizativos de la Administración y las legítimas expectativas de su personal a su progresión profesional. No nos vamos a detener en este complejo aspecto porque ello excedería el propósito de este artículo. Ahora bien el diseño del modelo de carrera que finalmente acabe implantando cada Administración Local debería insertarse en un modelo de gestión de personal más moderno que «fomente los aprendizajes necesarios y defina los itinerarios de carrera en un intento de armonizar las necesidades organizativas con los diferentes perfiles, expectativas e incluso preferencias individuales ${ }^{28} \gg$. Por el momento, nos basta simplemente con tener en cuenta que para los funcionarios públicos es posible articular un sistema en el que convivan ambos modelos de carrera. Ello dependerá por entero de la voluntad del legislador de desarrollo del Estatuto Básico. La clave estará en cómo hacerlos compatibles, toda vez que responden a lógicas muy diferentes. La carrera vertical está pensada para el acceso progresivo a puestos de trabajo de mayor responsabilidad en el organigrama organizativo de cada Administración y, en consecuencia, implica el cambio de puesto. La carrera horizontal, por el contrario, constituye la gran novedad del Estatuto. Ha sido calificada como la carrera de «los inmóviles ${ }^{29}$ », toda vez que la progresión en los grados o escalones no exige que el funcionario cambie de puesto de trabajo, al estar basada en la idea esencial de que la experiencia y el conocimiento enriquecen la forma de desempeño de un puesto de trabajo.

Ciertamente, todo este diseño está específicamente previsto para los funcionarios. Ahora bien, a mi juicio, no sería impensable que también pudiera llegar

\footnotetext{
26 Palomar Olmeda, Alberto y Sempere Navarro, Antonio, Comentarios al artículo 19 del Estatuto Básico, en la obra colectiva dirigida por estos dos autores y coordinada por Yolanda QUINTANILLA NAVARRO, titulada Comentarios a la Ley 7/2007, de 12 de abril, del Estatuto Básico del Empleado Público, Thomson, Aranzadi, Navarra, 2008, pág. 193.

27 FÉREZ FERNÁNDEZ, Manuel, La carrera administrativa: nuevas perspectivas, Editado por la Diputación de Barcelona, septiembre de 2006, págs. 22 y siguientes, destaca el papel institucional que debe tener la carrera, pues no puede desconocerse que también ha de tener como objetivo fundamental proporcionar a la Administración las personas con la capacidad necesaria para asegurar la gestión eficaz de los intereses públicos y, en consecuencia, la adecuación de los empleados a las estrategias de la organización para la producción de resultados acordes con las finalidades perseguidas por ésta.
}

28 Seguimos a LONGO MARTínEZ, Francisco, Mérito y flexibilidad. La gestión de las personas en las organizaciones del sector público, Paidós, Barcelona, 2004, págs. 142 y siguientes.

29 Parada VÁzQuez, Ramón, Derecho del Empleo Público, Marcial Pons, Madrid, 2007. 
a establecerse un sistema de carrera horizontal similar al funcionarial para el personal laboral de las entidades locales. Ello permitiría a este colectivo progresar sin necesidad de cambiar de puesto concreto de trabajo. Se trataría meramente de una posibilidad que podría preverse en los convenios colectivos, incluso establecerse sólo para determinadas categorías de personal, pues las modalidades que admitiría serían múltiples. Por otra parte, la eventual fijación de un modelo de carrera horizontal para el personal laboral podría resultar factible en la medida en que, a diferencia de lo que ocurre con la carrera vertical, no está conectada con la estructura de puestos y, en consecuencia, con el modelo organizativo de la Administración Local. A mayor abundamiento, además, el ámbito local resulta un campo especialmente idóneo para el establecimiento de un modelo de carrera horizontal, toda vez que suelen ser precisamente en las pequeñas Entidades Locales donde mayores dificultades plantea cualquier modelo de promoción profesional por la escasez de puestos de trabajo existentes.

De optarse por esta posibilidad, entiendo que la configuración del nuevo modelo de carrera no debería ser completamente libre para las partes negociadoras del convenio colectivo. Por el contrario, de una lectura integradora de los distintos preceptos del Estatuto podrían deducirse las premisas para su establecimiento. A mi juicio, lo lógico sería que se estableciera de forma análoga a la que, en su caso, previera el legislador de desarrollo para sus funcionarios autonómicos y para los funcionarios locales de todos los municipios de la Comunidad Autónoma. Ello debería ser así, en mi opinión, porque no tendría sentido que se establecieran a través de la negociación colectiva - y aisladamente respecto del personal funcionarial de la corporación - , modelos de «carrera laboral horizontal» que fueran muy diferentes de los de la carrera horizontal funcionarial que en su caso se establezcan, pues en ambos casos la carrera ha de responder a las mismas necesidades y objetivos. Recordemos que esta pretendida unificación o igualación de regímenes es la nueva filosofía inspiradora de la reforma. Como puso de manifiesto el informe realizado por la Comisión para el Estudio y Preparación del Estatuto Básico del Empleado Público, de abril de 2005, si con el establecimiento de un buen diseño de carrera se trata de mejorar el rendimiento y la productividad de todos los empleados, así como con el objetivo de reforzar la motivación y la satisfacción personal de cada empleado público, este objetivo ha de ser también válido y perfectamente aplicable para el colectivo de personal laboral ${ }^{30}$. En ambos colectivos, pues, la carrera ha de responder a las mismas necesidades y objetivos, que no son otros que los de aumentar el rendimiento y la productividad, a la vez que aumentar el grado de motivación de los empleados públicos.

\footnotetext{
30 Según da cuenta Manuel FÉREZ FERnÁndEZ, Op. Cit., pág. 20, en el Libro Azul elaborado por el equipo nombrado por el Ministro Almunia en el año 1989, titulado Reflexiones para la modernización de la Administración del Estado, ya se planteaba la necesidad de revisar el modelo de carrera para «posibilitar una progresión de la situación administrativa y retributiva de los funcionarios, que estimule su permanencia en la Administración, su profesionalización y la mejora de su rendimiento, con la finalidad última de conseguir una mayor eficacia de la gestión de los servicios públicos».
} 
Por otra parte, el convenio debería recoger las prescripciones mínimas y fundamentales que prevé el art. 17 del Estatuto Básico al regular las exigencias de la carrera horizontal funcionarial, a saber, el previo establecimiento de un sistema de grados, tramos o escalones que permitieran también para el personal laboral su ascenso consecutivo sin necesidad de cambiar de puesto, así como la fijación de los criterios que se seguirían para hacer efectiva esa carrera, en el que necesariamente se tendrían que valorar otros componentes distintos del de la mera antigüedad. A mi juicio, el establecimiento de un diseño basado únicamente en el componente de la antigüedad daría al traste con el objetivo incentivador que se ha de perseguir con esta nueva institución. Al respecto, debe ser componente obligado la evaluación del desempeño, toda vez que esta herramienta debe ser común para ambos colectivos de personal. Otros aspectos que podrían valorarse podrían ser la trayectoria profesional, la calidad de los trabajos o cualquier otro tipo de méritos y aptitudes que así puedan recogerse en el correspondiente convenio colectivo.

\section{PROBLEMAS PARA QUE LA EQUIPARACIÓN DE AMBOS REGÍMENES JURÍDICOS SEA REAL: UNA CUESTIÓN DE FUENTES}

A pesar de que la «unificación» de regímenes jurídicos es una de las principales pretensiones confesadas del Estatuto Básico, el régimen concreto y contenido sustantivo que se le acabe dando después a cada uno de estos derechos dependerá de fuentes muy distintas. Su determinación para el colectivo funcionarial local obedecerá a lo que disponga en última instancia el legislador de desarrollo, que supuestamente será el legislador autonómico ${ }^{31}$, previa negociación con las organizaciones sindicales cuando ello corresponda, según lo dispuesto en el art. 37 del Estatuto Básico ${ }^{32}$. Conviene tener presente que la determinación de los derechos de los funcionarios locales es una materia sometida a reserva de ley. Según interpretó tempranamente el Tribunal Constitucional en su Sentencia 99/1987, de 11 de junio, al definir el concepto constitucional de «estatuto de los funcionarios» mencionado en el artículo 103.3 de la Constitu-

\footnotetext{
31 Según contempla el artículo 3 del Estatuto Básico, el personal funcionarial en el ámbito local se rige por «la legislación estatal que resulte de aplicación, de la que forma parte este Estatuto y por la legislación autonómica». Es decir, el precepto ha sido redactado con tanta ambigüedad que no impide en modo alguno la posibilidad de que a través de la legislación básica de régimen local o del resto de legislación sectorial puedan introducirse regulaciones básicas para los funcionarios locales. En este punto, el legislador estatutario se ha apartado de las recomendaciones que había realizado el Informe del Comité de Expertos, que había destacado la conveniencia de clarificar el sistema de prelación de fuentes aplicables a los funcionarios locales y de que a éstos les resultara aplicable la legislación de desarrollo que elaborara la respectiva Comunidad Autónoma para su propio personal, salvo excepción justificada y respetando la autonomía local. Esta postura, además de ser la más lógica por la mayor proximidad y permeabilidad existente entre los funcionarios autonómicos y los locales, contribuiría en gran medida a solucionar los problemas de inseguridad jurídica que ahora se plantean por la dispersión normativa existente en la regulación de este colectivo.

32 El Estatuto Básico del Empleado Público establece una importante novedad en materia de derechos, al abrir la negociación colectiva funcionarial a las vacaciones, permisos, jornada, calendario laboral y horarios.
} 
ción, dejó sentado que «...es éste, desde luego, un ámbito cuyos contornos no pueden definirse en abstracto y a priori, pero en el que ha de entenderse comprendida, en principio, la formación relativa a la adquisición y pérdida de la condición de funcionario, a las condiciones de promoción en la carrera administrativa y a las situaciones en que ésta pueda darse, a los derechos y deberes y responsabilidad de los funcionarios y a su régimen disciplinario, así como a la creación e integración, en su caso, de Cuerpos y Escalas funcionariales y al modo de provisión de puestos de trabajo al servicio de las Administraciones Públicas». Significa ello que, al carecer las Entidades Locales de potestades legislativas, el régimen de derechos de los funcionarios locales quedará congelado una vez que se produzca la intervención del legislador de desarrollo ${ }^{33}$. Por el contrario, para el colectivo del personal laboral local, la concreción de dichos derechos se realizará directamente a través de los convenios colectivos, donde el ámbito de la negociación es muchísimo más dinámico y prácticamente ilimitado al regirse por el principio de autonomía colectiva.

No existe, pues, ninguna garantía de que, una vez lograda esta equiparación de derechos en el punto inicial de partida (en el Estatuto Básico), puedan después establecerse derechos nuevos para los trabajadores locales o condiciones mucho más ventajosas que las legalmente previstas para aquellos funcionarios que comparten Administración y, en no pocas ocasiones, incluso tareas. Además, esta potencial diferenciación de derechos a la que puede llegarse no podría ser objeto de ningún reproche jurídico, pues todavía sigue vigente la doctrina elaborada por nuestra jurisprudencia sobre el principio de tratamiento no unitario por diferenciado entre ambos colectivos. Según ha reconocido el Tribunal Constitucional, entre otras, en la recién mencionada Sentencia 99/1987, de 11 de junio, no se puede decir que la diferencia de trato legislativo entre laborales y funcionarios sea arbitraria. «Se trata de regímenes jurídicos distintos, aplicables a situaciones diferentes, es decir, uno estatutario y otro laboral, puesto que no son los mismos los derechos y deberes de uno y otro personal y es razonable esa distinción ya que, como se dijo en la STC 57/1982, fundamento jurídico 9. ${ }^{\circ}$, la igualdad de trato de funcionarios y trabajadores no se infiere de la Constitu-

\footnotetext{
33 Lo mismo ocurre en materia de promoción profesional. Así, la STS de 12 de marzo de 2008 (Sala de lo Contencioso-Administrativo, Sección Séptima), ha anulado diversos aspectos del Acuerdo XII ARCEPAFE relativos al sistema protector complementario de prestaciones pasivas y al fomento de la promoción interna, al considerar que el sistema de promoción profesional de los funcionarios locales queda al margen de la negociación colectiva por carecer las Entidades Locales de competencia para su regulación, por venir ésta establecida en la normativa estatal básica dictada en ejercicio de la competencia conferida por el artículo 149.1.18. ${ }^{\mathrm{a}}$ de la Constitución; artículo 100.2 de la Ley 7/1985, artículo 169.2 del Real Decreto Legislativo 781/1986 y el RD 896/1991. En concreto, el Acuerdo había previsto la reserva de un porcentaje de plazas para el ingreso a la Subescala Subalterna, toda vez que al no contemplar el RD 896/1991 previsión alguna acerca del porcentaje que debía reservarse a la promoción interna, se había interpretado que su establecimiento quedaba abierto a la negociación colectiva en los términos del art. 32, g, de la ley 9/1987. El análisis de este marco normativo permite finalmente al TS declarar que la regulación contemplada en el Acuerdo se sitúa al margen de la competencia atribuida en la materia a la Entidad Foral, con invasión del ámbito atribuido a la normativa básica estatal por el art. 169.2 del real Decreto Legislativo 781/1986, por lo que la sanción no ha de ser otra que la nulidad radical de los artículos del Acuerdo recurrido relativos al sistema de promoción profesional de sus funcionarios.
} 
ción, y de ello es prueba la también distinta regulación y previsión constitucional, cuyo art. 35.2 remite al Estatuto de los Trabajadores y el art. 103.3 al Estatuto de los funcionarios públicos, lo que justifica «las regulaciones diferenciadas, que no parecen irrazonables». Si la distinción entre ambos regímenes es una opción constitucionalmente lícita del legislador, también lo será la diferencia en los elementos configuradores de los mismos, no justificándose por ello la sospecha de arbitrariedad».

De todas formas, y a pesar de la idea que acabamos de apuntar, cierto es que en la mente del legislador básico estatutario ha prevalecido la idea de la unificación del régimen de los derechos y para lograr este objetivo ha establecido algunos mecanismos. Seguramente el más importante de todos ellos sea la instauración de mesas de negociación conjunta para laborales y funcionarios. Efectivamente, una de las principales novedades que se producen en este ámbito vendría referida a la obligación de llevar a cabo una negociación conjunta de todas aquellas materias y condiciones de trabajo comunes al personal funcionario, estatutario y laboral de cada Administración Local (art. 36.3 del EBEP). Con esta nueva estructura negociadora se viene a dar cobertura legal a una práctica de negociación conjunta que ya venía produciéndose en los últimos años, pero que sistemáticamente era anulada por nuestros tribunales ${ }^{34}$ ante la falta de previsión expresa por la regulación anterior, por la Ley 9/1987. Con muy buen criterio, a mi juicio, el legislador ha querido solucionar este problema dando cobertura legal a la creación de mesas de negociación conjunta de laborales y funcionarios donde se puedan tratar las materias que afecten a ambos colectivos, pues se ha entendido que resultaba contrario a los más elementales principios de la organización científica del trabajo que el mismo sujeto, esto es, la Administración, tuviera que llevar a cabo dos tipos de negociaciones sometidas a diferentes regímenes jurídicos y cuyo alcance y efectos jurídicos nada tenían que ver.

El cambio que se ha producido en esta materia resulta altamente significativo, pues el nuevo Estatuto Básico, no es que permita, sino que obliga a cada Entidad Local a tener tres mesas de negociación: una para su personal laboral, otra para el funcionarial y otra para ambos colectivos. Se entiende que a través de este dialogo conjunto se podrían sentar las bases idóneas para esta igualación sustantiva de regímenes jurídicos. Sin embargo, son varios los problemas que nos encontramos en la concreta materia de los derechos. Por una parte, no podemos olvidarnos de que, en rigor, en esta mesa conjunta no podría tratarse la materia relativa a los derechos pues, como hemos dicho antes, es ésta una materia sometida a reserva de ley y sobre la que, en consecuencia, no podría negociar la Administración Local. El artículo 37.1 del Estatuto es muy claro al delimitar el ámbito negociador de las Entidades Locales para sus funcionarios: sólo se negociará sobre las materias contempladas en el listado de dicho pre-

34 Entre otras, la Sentencia de la Sala Tercera del Tribunal Supremo 7544/1993 de 22 de octubre. 
cepto, con el alcance que legalmente proceda y en relación con las competencias de cada Administración. Resulta evidente que la Administración Local no dispone de competencias legislativas para regular los derechos de sus funcionarios, tal como antes hemos apuntado. Como empleadora, sin embargo, sí deberá negociar los derechos de su personal laboral.

Ello supone que los potenciales efectos equiparadores que puede tener esta nueva herramienta vendrían limitados, en rigor, al ámbito de los derechos de los empleados públicos autonómicos y de la Administración General del Estado. Es más, no existe ninguna garantía de que este objetivo se alcance finalmente, pues nada impide que después cada mesa de negociación de cada uno de los colectivos pueda apartarse conscientemente de esta pretensión unificadora si previamente no se logran ordenar de forma satisfactoria las relaciones de primacía o complementariedad entre estas estructuras de negociación. Al mismo tiempo, tampoco se puede saber la interpretación final que acabará dando la jurisprudencia en el supuesto de que se plantee algún problema interpretativo de los derechos, toda vez que cada uno de estos instrumentos negociadores (convenios colectivos, pactos y acuerdos funcionariales) será conocido por una jurisdicción diferente que, como es sabido, suele responder a sensibilidades muy diferentes ${ }^{35}$.

En definitiva, pues, la sumisión de cada uno de estos colectivos a fuentes diferentes puede llevar al traste este preciado objetivo unificador del legislador. En la medida en que el régimen de derechos de los funcionarios locales vendrá determinado por el legislador autonómico y el régimen de derechos del personal laboral de las Entidades Locales por los convenios colectivos, nada frenaría la posibilidad de que pudieran establecerse regímenes distintos y más beneficiosos todavía para el colectivo laboral, pues para ellos no existe prácticamente otra limitación que los topes máximos salariales que anualmente se fijan en la Ley de Presupuestos Generales del Estado.

\footnotetext{
35 Cierto es, no obstante, que en algunas sentencias dictadas en el ámbito de la Jurisdicción Social se empieza a apreciar cierta sensibilidad con los principios que rigen la actividad administrativa. Así, puede traerse nuevamente a colación la STS de 20 de enero de 2009, que ha recurrido al principio de «eficacia» que ha de regir la actuación de las Administraciones Públicas, entre otros argumentos, para evitar una interpretación extensiva de una norma autonómica que había previsto determinados derechos de reducción de jornada para sus empleados públicos y con la finalidad de favorecer la conciliación de la vida laboral y familiar.
} 